\title{
Null Subjects in Early Icelandic
}

\author{
Kari Kinn \\ University of Oslo \\ Kristian A. Rusten \\ Bergen University College \\ George Walkden \\ University of Manchester
}

\begin{abstract}
This paper investigates the possibility of subject omission in the history of Icelandic, including the syntactic and pragmatic conditions under which it could arise. Based on regression analysis of substantial data drawn from the IcePaHC corpus, we provide robust quantitative support for Hjartardóttir's (1987) claim that null subjects persist until a very late stage in Icelandic. We also argue, contra Sigurðsson (1993), that only one licensing mechanism is needed for null subjects in early Icelandic. Moreover, on the basis of the position of the null subjects and their person features, we argue that the modern stage, where (predominantly 3rd person) pro-drop yields to a system permitting topic drop of all persons, arises in Icelandic in the early twentieth century.
\end{abstract}

\section{Introduction.}

In this paper, we investigate the possibility of subject omission in the history of Icelandic, including the syntactic and pragmatic conditions

We would very much like to thank Anton Karl Ingason for graciously answering our inquiries concerning the IcePaHC corpus and the CorpusSearch 2 program, Heimir Freyr Viðarsson for help with examples, and two anonymous reviewers for JGL for their constructive suggestions. We would also like to thank Gard B. Jenset for kindly allowing us to use a Python script, written by him, which greatly simplified the process of collating data from various CorpusSearch output files. Thanks also to the audience at the Workshop on Understanding Pro-Drop held in Trento in June 2014, for their insightful questions and comments. 
under which it could arise. The empirical basis for our study is the Icelandic Parsed Historical Corpus (IcePaHC; Wallenberg et al. 2011), a parsed corpus of historical Icelandic prose from the earliest records to the present day. Previous research by Sigurðsson (1993), building on empirical work by Hjartardóttir (1987), has outlined the basic possibilities for argument drop in Old Icelandic (1150-1400) and presented a syntactic analysis. Nevertheless, there are numerous reasons to revisit the topic at this point, ranging from the empirical to the theoretical to the typological.

From an empirical perspective, the availability of the IcePaHC permits us to fill the lacunae present in earlier studies. The possibility of subject omission has been noted in the literature since Nygaard 1894:4 5, and Hjartardóttir (1987) provides a broad selection of examples from texts of the 13th-19th centuries. However, claims about argument drop in Icelandic have never been put to the test quantitatively. For instance, Nygaard (1906:8-9) observes that 1st and 2nd person null subjects are rarer than 3rd person null subjects (see also Sigurðsson 1993:253). Is this the case, and if so, how much rarer? Only a quantitative study of a large balanced corpus can answer this kind of question, and the IcePaHC allows us to conduct quantitative and qualitative research on a scale not possible before. One particularly important fact here is that, as noted by Sigurðsson (1993:249), no significant weakening of verbal morphology has taken place in the recorded history of Icelandic, and yet the language has nevertheless lost certain kinds of null subjects. This is in stark contrast to other languages in which there has been a change in the availability of null subjects and in which it is possible to investigate that change in detail in the historical record, such as French (see Vance 1989, Roberts 1993, Zimmerman 2014) and Brazilian Portuguese (see Duarte 1995 and Modesto 2000).

From a theoretical perspective, the understanding of the issue has come a long way since the last detailed treatment by Sigurðsson (1993), over 20 years ago. Sigurðsson's discussion is framed in late Government $\&$ Binding (GB) terms. Since then, however, the move to Minimalism has forced scientists to rethink their theoretical approaches to null subjects by questioning the status of empty categories such as pro and PRO, as well as principles such as the ECP. In recent years, even the parametric approach to null subjects as developed in most GB and 
Minimalist work since Rizzi 1982 has been called into question (see Sigurðsson 2011).

Relatedly, significantly more is now known about the typology of null argument languages than twenty years ago: Alongside consistent and radical null subject languages, expletive null subject languages and at least one type of partial null subject language must also be recognized (see Huang 2000; Holmberg 2005; Barbosa 2009, 2011, 2013; Holmberg \& Roberts 2010). Furthermore, the explosion of work on the syntax and pragmatics of the left periphery since Rizzi 1997 has led to progress in understanding of the discourse conditions under which arguments may be null (see Frascarelli 2007 and subsequent work). All of these developments offer new perspectives with which to approach the Icelandic data.

Finally, the null subject properties of related early Germanic languages have become much better understood in the last decade or so. Old English has been investigated by van Gelderen (2000, 2013), Walkden (2013, 2016), and Rusten (2013, 2015); Old High German by Axel (2007) and Axel \& Weiß (2011); Old Norwegian by Kinn (2014, 2015); Old Swedish by Falk (1992), Magnusson (2003), and Håkansson (2008, 2013); Old Saxon by Walkden (2014); and Gothic by Fertig (2000) and Ferraresi (2005). Rosenkvist (2009) and Walkden (2014:157226) provide a comparative perspective: In general, the early Germanic languages, with the exception of Gothic, display a remarkable homogeneity with regard to the conditions under which null arguments may occur. It is therefore of interest to see to what extent Old Icelandic contrasts with its sister languages, and to what extent it displays the same behavior.

The null argument property of Old Icelandic/Old Norse is discussed to varying degrees of detail in Nygaard 1894, 1906, Thráinsson \& Hjartardóttir 1986, Hjartardóttir 1987, Sigurðsson 1989, Faarlund 1994, 2004, Hróarsdóttir 1996, Lander \& Haegeman 2014, and Walkden 2014. ${ }^{1}$ However, the most influential and in-depth study to date is that of

\footnotetext{
${ }^{1}$ Since the IcePaHC contains exclusively (Old) Icelandic material, we avoid the term Old Norse in this paper. The term is problematic, as it has been used to denote various time periods and subgroups, including Old West Norse and the common ancestor of all the Scandinavian languages; much of the earliest material in any case originates in Iceland. Unfortunately, not all previous authors have been careful to distinguish between these different varieties.
} 
Sigurðsson (1993), and it will serve as our main point of reference in this paper. Sigurðsson makes three main claims that are of relevance to our investigation:

(i) Old Icelandic had both topic drop and genuine pro-drop, with different licensing/identification mechanisms;

(ii) Dropping of $1 \mathrm{st}$ and 2 nd person arguments was very rare (see Nygaard 1894, 1906);

(iii) Icelandic did not lose its null argument property until the eighteenth and nineteenth centuries (based on Hjartardóttir 1987).

Sigurðsson's claims serve as hypotheses that we test against new data. To these can be added a fourth hypothesis, based on the distribution of null subjects in other early Northwest Germanic languages (see Rosenkvist 2009 and Walkden 2014): Null subjects are rarer in subordinate clauses than in main clauses. This is the case for at least the early West Germanic languages (Old English, Old High German, and Old Saxon), as well as Old Swedish. These four items are the hypotheses we are investigating in this paper. ${ }^{2}$

The paper is structured as follows: Section 2 describes the method we used to obtain our data. Section 3 presents and discusses quantitative results that bear on the effects of text and genre, distribution across clause types, the effect of person and number, and the date of the change. Section 4 addresses the first hypothesis mentioned above: Can a principled case be made for distinguishing two types of argument drop in early Icelandic? This section also addresses the nature of the change that has taken place in the licensing of null arguments, and sketches a syntactic analysis. Section 5 discusses the extent to which the Icelandic

\footnotetext{
${ }^{2}$ Sigurðsson (1993) addresses object drop as well as subject drop, as examples of both can be found. He argues that both topic drop and pro-drop can give rise to object omission. We do not address null objects in this paper, as a systematic study would require a full understanding of the subcategorization frames of lexical verbs in order to determine whether they are transitive (and do not allow optional detransitivization as in English Mary ate). We leave such a study to future research, noting that the existing lemmatization of the IcePaHC would greatly facilitate the task.
} 
findings converge with those for other Northwest Germanic languages. Section 6 then summarizes and concludes.

\section{Methodology.}

The present investigation harnesses corpus-linguistic methods of data collection and data handling. It is based on extensive empirical material drawn from the IcePaHC corpus, which comprises 1,002,390 words and consists of sizable samples from 61 texts covering the period 1150-2008 CE. This enables us to conduct a large-scale, empirically-based longitudinal investigation that places under scrutiny ca. 850 years of the history and development of Icelandic. Moreover, the texts contained in the corpus represent a wide variety of genres and registers, and should therefore provide an eminently representative base for generalizations concerning the null subject property in the history of Icelandic.

Using the CorpusSearch 2 program (Randall et al. 2005-2013), searches were run to extract all occurrences of overt and null pronominal subjects from all 61 texts in the corpus. This investigation concerns itself exclusively with empty subjects tagged *pro*, as in 1a. Thus, subjects elided under coordination (tagged *con*, as in $1 \mathrm{~b}$ ), and empty expletive subjects (tagged ${ }^{*} \exp ^{*}$, as in 1c) have not been considered. ${ }^{3}$

(1) a. Pegar [pro] par kom, pá stóðu herramenn [...] when $[\mathrm{pro}]$ there came, then stood noblemen $[\ldots]$

um allan slotsgarðinn.

about all courtyard-DEF

'When he came there, there stood noblemen all around the courtyard.'

(1661.INDIAFARI.BIO-TRA,66.1096)

\footnotetext{
${ }^{3}$ In this and the following examples, we use pro to indicate that a clause has a null subject, without committing ourselves to the existence of pro in the GB sense as a theoretical entity. The abbreviation $e$ denotes subjects elided under coordination, empty subjects that we analyze as topic drop, as well as empty expletive subjects. We use the following abbreviations for grammatical categories: $\quad \mathrm{ACC}=$ accusative, $\mathrm{ADJ}=$ adjective, $\mathrm{DAT}=$ dative, $\mathrm{DEF}=$ definite, $\mathrm{DET}=$ determiner, $\mathrm{GEN}=$ genitive, $\mathrm{IMP}=$ imperative, $\mathrm{NOM}=$ nominative, $\mathrm{PL}=$ plural, $\mathrm{REFL}=$ reflexive, $\mathrm{SBV}=$ subjunctive, $\mathrm{SG}=$ singular.
} 
b. Porvarður gekk pá til dómsmanna og [e] segir: Porvarður walked then to dooms.man and $[e]$ says "Segið upp dóminn"
say-IMP up doom-DEF

'Porvarður then went to the judge and said: 'announce the judgement.', (1325.ARNI.NAR-SAG,.523)

c. Og pá hann hafði bitann tekið and when he had piece.of.bread-DEF taken

gekk hann strax út og pá var $[e]$ nótt. walked he immediately out and then was $[e]$ night

'And when he had taken the bread, he immediately went out, and it was then night.'

(1540.NTJOHN.REL-BIB,217.1134-1135)

It should be noted that the IcePaHC annotators tag as oblique subjects all non-nominative noun phrases that are subjects in present-day Icelandic. We have adhered to the IcePaHC annotation. ${ }^{4}$ In the interests of exhaustiveness, then, all overt and null subjects have been extracted, whether nominative or non-nominative. Searches for both overt and null pronominal subjects were restricted to those occurring in finite clauses.

Following extraction, the dataset was manually enriched with information on person and number, as the corpus texts are not tagged for these features. Thus, all citations containing a null subject token have been examined manually. The make lexicon feature in CorpusSearch

${ }^{4}$ Whether Old Icelandic (or early Scandinavian more broadly) had nonnominative, oblique, or so-called quirky subjects is still a matter of debate. Work by Rögnvaldsson (1991, 1995) presents arguments that it did; he is followed by Haugan (1998), Barðdal (2001), Eythórsson \& Barðdal (2005), Barðdal \& Eythórsson (2012), and Ingason et al. (2011). In contrast, Faarlund (2001, 2004) argues that subjects in earlier stages of Scandinavian were nominative. The crucial data are based on judgments of low-frequency phenomena that are difficult to find in historical corpora. We do not take a stand on this issue here but for simplicity's sake follow the annotators in assuming the existence of oblique subjects throughout the history of Icelandic. 
was utilized in order to ascertain that all collected overt pronominal subject tokens were fit for inclusion in the dataset. Any obviously mistagged tokens identified as overt pronominal subjects were discarded. In the case of the null subjects, it was noted that it occasionally may be questioned whether a token identified as * pro* would be better analyzed as *exp*. This is, however, often a challenging distinction, and one that is certainly much less clear-cut than the cases of mistagged overt pronouns referred to above. Thus, since this problem affects no more than a restricted number of tokens, and since the quantitative results are not influenced, we have opted to accept the IcePaHC annotation as concerns the distinction between expletive and nonexpletive null subjects. On the basis of similar considerations, we have also accepted the IcePaHC annotation of some null subjects that should perhaps rather be analyzed as imperative subjects or as instances of conjunction reduction. ${ }^{5}$

The results presented in this paper have been tested statistically by means of a generalized mixed-effects logistic regression model computed in Rbrul (Johnson 2009). The regression model takes "text" and "genre" as random effects, and "year", "person", "number", and "type" as fixed effects. In addition, we tested for possible interaction between "year" and "person" and between "year" and "type". The predictors of "text", "year", "genre", "person", and "number" should be self-explanatory. The final predictor, "type", specifies the clausal environment of the pronominal token, whether occurring in a verb-initial main clause, a nonverb-initial main clause, a verb-initial conjunct clause, a non-verb-initial conjunct clause, or a subordinate clause.

Mixed-effects regression modeling offers several advantages over both nonparametric null hypothesis tests, such as Pearson's chi-squared test, and nonhierarchical generalized linear models, such as those commonly used in sociolinguistics since the 1970s (see, for example, the references in Tagliamonte \& Baayen 2013:142). First, it is well known that the chi-squared test is sensitive to sample size (see, for example, Mosteller 1968:2), such that deceptively low probability values are

\footnotetext{
${ }^{5}$ Significantly, these decisions make it convenient for the interested researcher to replicate our results.
} 
frequently reported with large datasets. ${ }^{6}$ Additionally, computation of the effect of several variables in a single contingency table can cause spuriously low probability values (see, for example, Jenset 2010:81). Logistic regression modeling allows us to represent a linguistic phenomenon (in our case, realization of a pronominal subject) as a binary response - that is, as overt or null-while relating that response to a number of hypothetically relevant variables simultaneously, while avoiding the weaknesses of the chi-squared test.

Second, unlike nonhierarchical generalized regression models, mixed-effects models can account for both fixed and random effects. ${ }^{7}$ In the case of this investigation, "text" and "genre" are clearly random effects: Many more Icelandic texts exist than those included in the corpus, and it cannot be assumed that the genres represented in the IcePaHC exhaust the possible range of genres. If random effects are treated as fixed by the statistical model, the results of the regression analysis would not technically be generalizable beyond the specific texts and genres investigated (see, for example, Baayen 2008:241). Mixedeffects modeling eliminates this problem, and is therefore preferable to nonhierarchical regression modeling. Finally, all Icelandic examples cited in this article are taken from the text of the IcePaHC and carry the corpus identification label, which indicates the text ID, as well as the date of composition and genre of the text in question.

\section{Results.}

\subsection{Overview.}

Table 1 gives an overview of the occurrence of overt and null pronominal subjects in the IcePaHC. In table 1, relative frequencies for null subjects are given as a percentage of the total number of pronominal subjects. The results are illustrated in figure 1 .

\footnotetext{
${ }^{6}$ This paper places under scrutiny 48,649 pronominal tokens, meaning that any statistically significant results obtained by means of the chi-squared test could potentially be ascribed to sheer sample size.

${ }^{7}$ Fixed effects are variables whose values exhaust the possible range of variation. For example, "person" is a fixed effect, since 1st, 2nd, and 3rd person are the only possible values. In contrast, random effects do not exhaust the possible range of variation.
} 


\begin{tabular}{|c|c|c|c|c|}
\hline Text & Overt & Null & Total & \% null \\
\hline 1150.FIRSTGRAMMAR.SCI-LIN & 175 & 46 & 221 & $20.8 \%$ \\
\hline 1150.HOMILIUBOK.REL-SER & 1821 & 49 & 1870 & $2.6 \%$ \\
\hline 1210.JARTEIN.REL-SAG & 463 & 45 & 508 & $8.9 \%$ \\
\hline 1210.THORLAKUR.REL-SAG & 520 & 17 & 537 & $3.2 \%$ \\
\hline 1250.STURLUNGA.NAR-SAG & 926 & 30 & 956 & $3.1 \%$ \\
\hline 1250.THETUBROT.NAR-SAG & 155 & 3 & 158 & $1.9 \%$ \\
\hline 1260.JOMSVIKINGAR.NAR-SAG & 1012 & 30 & 1042 & $2.9 \%$ \\
\hline 1270.GRAGAS.LAW-LAW & 268 & 44 & 312 & $14.1 \%$ \\
\hline 1275.MORKIN.NAR-HIS & 1167 & 95 & 1262 & $7.5 \%$ \\
\hline 1300.ALEXANDER.NAR-SAG & 942 & 28 & 970 & $2.9 \%$ \\
\hline 1310.GRETTIR.NAR-SAG & 1088 & 36 & 1124 & $3.2 \%$ \\
\hline 1325.ARNI.NAR-SAG & 672 & 36 & 708 & $5.1 \%$ \\
\hline 1350.BANDAMENNM.NAR-SAG & 745 & 51 & 796 & $6.4 \%$ \\
\hline 1350.FINNBOGI.NAR-SAG & 1404 & 49 & 1453 & $3.4 \%$ \\
\hline 1350.MARTA.REL-SAG & 873 & 10 & 883 & $1.1 \%$ \\
\hline 1400.GUNNAR.NAR-SAG & 547 & 19 & 566 & $3.4 \%$ \\
\hline 1400.GUNNAR2.NAR-SAG & 161 & 6 & 167 & $3.6 \%$ \\
\hline 1400.VIGLUNDUR.NAR-SAG & 761 & 20 & 781 & $2.6 \%$ \\
\hline 1450.BANDAMENN.NAR-SAG & 702 & 49 & 751 & $6.5 \%$ \\
\hline 1450.ECTORSSAGA.NAR-SAG & 1074 & 59 & 1133 & $5.2 \%$ \\
\hline 1450.JUDIT.REL-BIB & 299 & 7 & 306 & $2.3 \%$ \\
\hline 1450.VILHJALMUR.NAR-SAG & 1299 & 66 & 1365 & $4.8 \%$ \\
\hline 1475.AEVINTYRI.NAR-REL & 994 & 41 & 1035 & $4.0 \%$ \\
\hline 1480.JARLMANN.NAR-SAG & 771 & 46 & 817 & $5.6 \%$ \\
\hline 1525.ERASMUS.NAR-SAG & 367 & 9 & 376 & $2.4 \%$ \\
\hline 1525.GEORGIUS.NAR-REL & 1002 & 43 & 1045 & $4.1 \%$ \\
\hline 1540.NTACTS.REL-BIB & 801 & 5 & 806 & $0.6 \%$ \\
\hline 1540.NTJOHN.REL-BIB & 1570 & 7 & 1577 & $0.4 \%$ \\
\hline 1593.EINTAL.REL-OTH & 1294 & 5 & 1299 & $0.4 \%$ \\
\hline 1611.OKUR.REL-OTH & 427 & 26 & 453 & $5.7 \%$ \\
\hline 1628.OLAFUREGILS.BIO-TRA & 719 & 26 & 745 & $3.5 \%$ \\
\hline 1630.GERHARD.REL-OTH & 613 & 5 & 618 & $0.8 \%$ \\
\hline
\end{tabular}




\begin{tabular}{lrrrr} 
1650.ILLUGI.NAR-SAG & 952 & 26 & 978 & $2.7 \%$ \\
1659.PISLARSAGA.BIO-AUT & 446 & 16 & 462 & $3.5 \%$ \\
1661.INDIAFARI.BIO-TRA & 889 & 79 & 968 & $8.2 \%$ \\
1675.ARMANN.NAR-FIC & 574 & 22 & 596 & $3.7 \%$ \\
1675.MAGNUS.BIO-OTH & 92 & 14 & 106 & $13.2 \%$ \\
1675.MODARS.NAR-FIC & 213 & 5 & 218 & $2.3 \%$ \\
1680.SKALHOLT.NAR-REL & 366 & 22 & 388 & $5.7 \%$ \\
1720.VIDALIN.REL-SER & 1061 & 13 & 1074 & $1.2 \%$ \\
1725.BISKUPASOGUR.NAR-REL & 435 & 47 & 482 & $9.8 \%$ \\
1745.KLIM.NAR-FIC & 935 & 10 & 945 & $1.1 \%$ \\
1790.FIMMBRAEDRA.NAR-SAG & 874 & 11 & 885 & $1.2 \%$ \\
1791.JONSTEINGRIMS.BIO-AUT & 1213 & 77 & 1290 & $6.0 \%$ \\
1830.HELLISMENN.NAR-SAG & 568 & 32 & 600 & $5.3 \%$ \\
1835.JONASEDLI.SCI-NAT & 87 & 2 & 89 & $2.2 \%$ \\
1850.PILTUR.NAR-FIC & 899 & 19 & 918 & $2.1 \%$ \\
1859.HUGVEKJUR.REL-SER & 913 & 4 & 917 & $0.4 \%$ \\
1861.ORRUSTA.NAR-FIC & 777 & 31 & 808 & $3.8 \%$ \\
1882.TORFHILDUR.NAR-FIC & 1064 & 19 & 1083 & $1.8 \%$ \\
1883.VOGGUR.NAR-FIC & 70 & 0 & 70 & $0.0 \%$ \\
1888.GRIMUR.NAR-FIC & 338 & 1 & 339 & $0.3 \%$ \\
1888.VORDRAUMUR.NAR-FIC & 487 & 2 & 489 & $0.4 \%$ \\
1902.FOSSAR.NAR-FIC & 936 & 21 & 957 & $2.2 \%$ \\
1907.LEYSING.NAR-FIC & 771 & 7 & 778 & $0.9 \%$ \\
1908.OFUREFLI.NAR-FIC & 1163 & 25 & 1188 & $2.1 \%$ \\
1920.ARIN.REL-SER & 863 & 8 & 871 & $0.9 \%$ \\
1985.MARGSAGA.NAR-FIC & 1175 & 21 & 1196 & $1.8 \%$ \\
1985.SAGAN.NAR-FIC & 751 & 49 & 800 & $6.1 \%$ \\
2008.MAMMA.NAR-FIC & 1504 & 15 & 1519 & $1.0 \%$ \\
2008.OFSI.NAR-SAG & 973 & 22 & 995 & $2.2 \%$ \\
\hline Grand total & 47021 & 1628 & 48649 & $3.3 \%$ \\
\hline & & & & \\
& & &
\end{tabular}

Table 1. Overt versus null subjects in the IcePaHC (Wallenberg et al. 2011). 


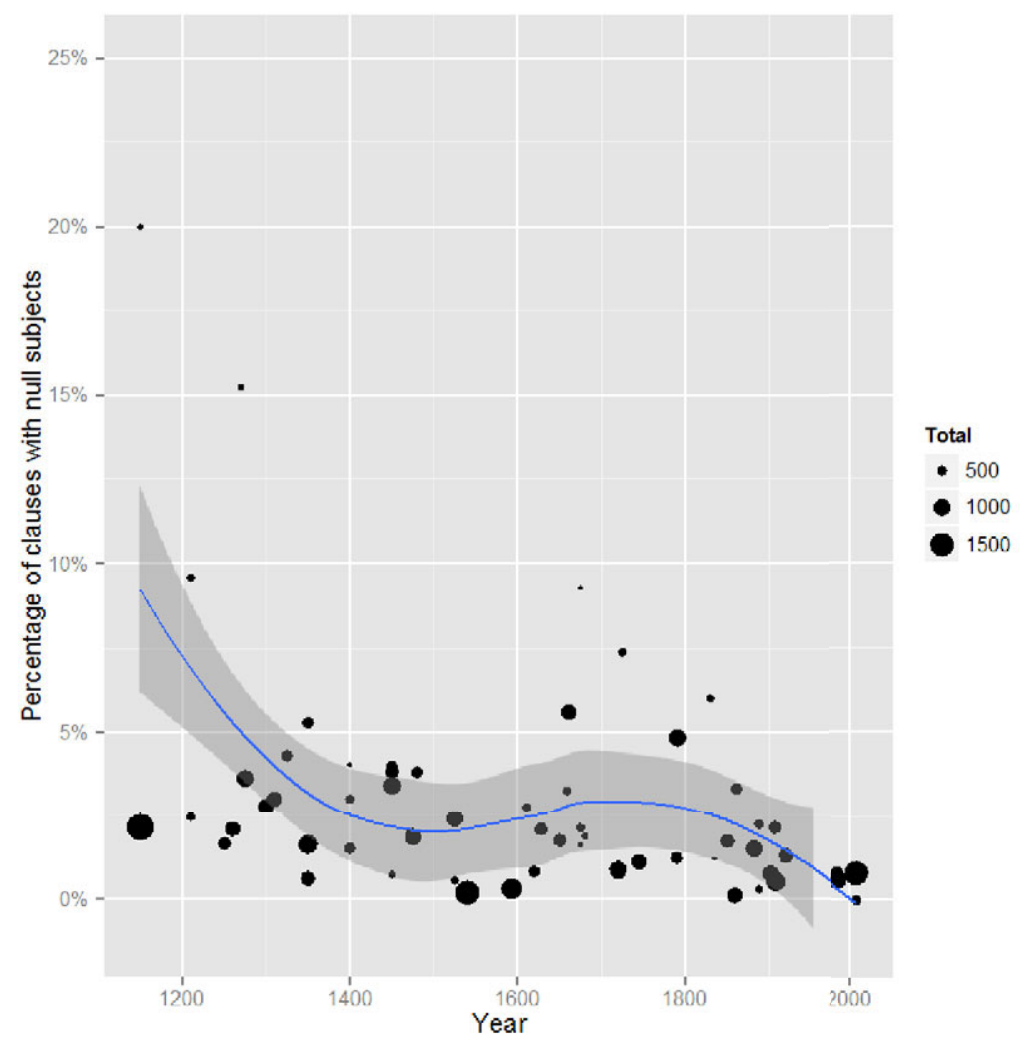

Figure 1. Null subjects by text across time.

Table 1 shows that null subjects occur at an overall relative frequency of $3.3 \%$ in 61 Icelandic texts composed between ca. 1150 and 2008. Although the data in the table are characterized by considerable variation, a number of the texts feature null subjects at quite robust frequencies. For example, $20.8 \%$ of all pronominal subjects are realized as null subjects in the First Grammatical Treatise (composed ca. 1150). Null subjects occur at frequencies of $8.9 \%$ in the Jarteinabók (ca. 1210) and $14.1 \%$ in Grágás (ca. 1270).

Moreover, the table demonstrates that relatively robust frequencies for null subjects occur well beyond the Old Icelandic period: Um aett Magnúsar Jónssonar (1675) and Biskupasögur Jóns prófasts Halldórssonar i Hitardal (1725) display frequencies for null subjects of 
$13.2 \%$ and $9.8 \%$, respectively. It is also notable that $5.3 \%$ and $3.8 \%$ of all pronominal subjects are null in Hellismanna saga and Orrusta, which were published in 1830 and 1861, respectively. This finding provides substantial quantitative corroboration of the claims put forward by Hjartardóttir (1987) concerning the longevity of the null subject property in Icelandic.

Even so, the commonness of null subjects in Icelandic should not be overstated: It is evident on casual perusal of table 1 and figure 1 that null subjects are not a highly frequent phenomenon at any stage of the language - a fact highlighted by the relatively low overall frequency of $3.3 \%$ for the entire period under investigation. Null subjects are found at a frequency of less than $1.5 \%$ in 15 of 61 texts, whereas another 16 texts have frequencies in the range of $1.8 \%-2.9 \%$. Only three texts display frequencies exceeding $10 \%$, yet 14 texts feature null subjects at frequencies ranging from $5.1 \%$ to $9.8 \%$. On the basis of the data in table 1 , then, it can be concluded that null subjects are a low-frequency but stable phenomenon in the Icelandic texts under analysis, with higher frequencies generally occurring in texts from early stages of Icelandic.

\subsection{Effects of Text and Genre.}

In the regression model, both text and genre were taken as random effects. Tables 2 and 3 give the strength of these effects.

\begin{tabular}{lrrrr}
\hline Text & Intercept & Tokens & $\begin{array}{c}\mathbf{n} / \\
\mathbf{n + y}\end{array}$ & $\begin{array}{r}\text { Centered } \\
\text { factor } \\
\text { weight }\end{array}$ \\
\hline 1985.SAGAN.NAR-FIC & & & & \\
1150.FIRSTGRAMMAR.SCI-LIN & 1.353 & 800 & 0.061 & 0.794 \\
1450.BANDAMENN.NAR-SAG & 1.065 & 751 & 0.065 & 0.743 \\
1725.BISKUPASOGUR.NAR-REL & 1.01 & 482 & 0.098 & 0.732 \\
1350.BANDAMENNM.NAR-SAG & 1.002 & 796 & 0.064 & 0.731 \\
1611.OKUR.REL-OTH & 0.831 & 453 & 0.057 & 0.696 \\
1661.INDIAFARI.BIO-TRA & 0.582 & 968 & 0.082 & 0.641 \\
1480.JARLMANN.NAR-SAG & 0.562 & 817 & 0.056 & 0.636 \\
1675.MAGNUS.BIO-OTH & 0.521 & 106 & 0.132 & 0.626 \\
1908.OFUREFLI.NAR-FIC & 0.516 & 1188 & 0.021 & 0.625 \\
1902.FOSSAR.NAR-FIC & 0.414 & 957 & 0.022 & 0.599
\end{tabular}


1270.GRAGAS.LAW-LAW

1275.MORKIN.NAR-HIS

2008.OFSI.NAR-SAG

1985.MARGSAGA.NAR-FIC

1525.GEORGIUS.NAR-REL

1475.AEVINTYRI.NAR-REL

1450.ECTORSSAGA.NAR-SAG

1450.VILHJALMUR.NAR-SAG

1210.JARTEIN.REL-SAG

1791.JONSTEINGRIMS.BIO-AUT

1450.JUDIT.REL-BIB

1325.ARNI.NAR-SAG

1861.ORRUSTA.NAR-FIC

1525.ERASMUS.NAR-SAG

1920.ARIN.REL-SER

1400.GUNNAR.NAR-SAG

1680.SKALHOLT.NAR-REL

1350.FINNBOGI.NAR-SAG

1628.OLAFUREGILS.BIO-TRA

1830.HELLISMENN.NAR-SAG

1310.GRETTIR.NAR-SAG

2008.MAMMA.NAR-FIC

1720.VIDALIN.REL-SER

1675.ARMANN.NAR-FIC

1882.TORFHILDUR.NAR-FIC

1400.GUNNAR2.NAR-SAG

1300.ALEXANDER.NAR-SAG

1150.HOMILIUBOK.REL-SER

1659.PISLARSAGA.BIO-AUT

1650.ILLUGI.NAR-SAG

1250.THETUBROT.NAR-SAG

1675.MODARS.NAR-FIC

1883.VOGGUR.NAR-FIC

$\begin{array}{lrll}0.386 & 312 & 0.141 & 0.594 \\ 0.342 & 1262 & 0.075 & 0.584 \\ 0.329 & 995 & 0.022 & 0.581 \\ 0.291 & 1196 & 0.018 & 0.571\end{array}$

$\begin{array}{llll}0.258 & 1045 & 0.041 & 0.563\end{array}$

$\begin{array}{llll}0.239 & 1035 & 0.04 & 0.558\end{array}$

$\begin{array}{llll}0.209 & 1133 & 0.052 & 0.551\end{array}$

$\begin{array}{llll}0.159 & 1365 & 0.048 & 0.539\end{array}$

$\begin{array}{llll}0.143 & 508 & 0.089 & 0.535\end{array}$

$\begin{array}{llll}0.132 & 1290 & 0.06 & 0.532\end{array}$

$\begin{array}{llll}0.119 & 306 & 0.023 & 0.529\end{array}$

$\begin{array}{llll}0.095 & 708 & 0.051 & 0.523\end{array}$

$\begin{array}{llll}0.083 & 808 & 0.038 & 0.52\end{array}$

$\begin{array}{llll}0.072 & 376 & 0.024 & 0.517\end{array}$

$\begin{array}{llll}0.025 & 871 & 0.009 & 0.505\end{array}$

$\begin{array}{llll}0.002 & 566 & 0.034 & 0.5\end{array}$

$\begin{array}{llll}-0.014 & 388 & 0.057 & 0.496\end{array}$

$\begin{array}{llll}-0.033 & 1453 & 0.034 & 0.491\end{array}$

$\begin{array}{llll}-0.06 & 745 & 0.035 & 0.484\end{array}$

$\begin{array}{llll}-0.068 & 600 & 0.053 & 0.482\end{array}$

$\begin{array}{llll}-0.076 & 1124 & 0.032 & 0.48\end{array}$

$\begin{array}{llll}-0.089 & 1519 & 0.01 & 0.477\end{array}$

$\begin{array}{llll}-0.091 & 1074 & 0.012 & 0.476\end{array}$

$\begin{array}{llll}-0.111 & 596 & 0.037 & 0.471\end{array}$

$\begin{array}{llll}-0.115 & 1083 & 0.018 & 0.47\end{array}$

$\begin{array}{llll}-0.126 & 167 & 0.036 & 0.468\end{array}$

$\begin{array}{llll}-0.153 & 970 & 0.029 & 0.461\end{array}$

$\begin{array}{llll}-0.154 & 1870 & 0.026 & 0.461\end{array}$

$\begin{array}{llll}-0.164 & 462 & 0.035 & 0.458\end{array}$

$\begin{array}{llll}-0.231 & 978 & 0.027 & 0.442\end{array}$

$\begin{array}{llll}-0.238 & 158 & 0.019 & 0.44\end{array}$

$\begin{array}{llll}-0.267 & 218 & 0.023 & 0.433\end{array}$

$\begin{array}{llll}-0.279 & 70 & 0 & 0.43\end{array}$ 


\begin{tabular}{lrrrr} 
1400.VIGLUNDUR.NAR-SAG & -0.31 & 781 & 0.026 & 0.422 \\
1835.JONASEDLI.SCI-NAT & -0.317 & 89 & 0.022 & 0.42 \\
1630.GERHARD.REL-OTH & -0.324 & 618 & 0.008 & 0.419 \\
1850.PILTUR.NAR-FIC & -0.367 & 918 & 0.021 & 0.408 \\
1859.HUGVEKJUR.REL-SER & -0.438 & 917 & 0.004 & 0.391 \\
1888.GRIMUR.NAR-FIC & -0.449 & 339 & 0.003 & 0.389 \\
1888.VORDRAUMUR.NAR-FIC & -0.492 & 489 & 0.004 & 0.378 \\
1907.LEYSING.NAR-FIC & -0.495 & 778 & 0.009 & 0.378 \\
1540.NTACTS.REL-BIB & -0.497 & 806 & 0.006 & 0.377 \\
1540.NTJOHN.REL-BIB & -0.516 & 1577 & 0.004 & 0.373 \\
1745.KLIM.NAR-FIC & -0.537 & 945 & 0.011 & 0.368 \\
1260.JOMSVIKINGAR.NAR-SAG & -0.564 & 1042 & 0.029 & 0.362 \\
1250.STURLUNGA.NAR-SAG & -0.573 & 956 & 0.031 & 0.36 \\
1593.EINTAL.REL-OTH & -0.743 & 1299 & 0.004 & 0.321 \\
1210.THORLAKUR.REL-SAG & -0.809 & 537 & 0.032 & 0.307 \\
1790.FIMMBRAEDRA.NAR-SAG & -0.901 & 885 & 0.012 & 0.288 \\
1350.MARTA.REL-SAG & -1.021 & 883 & 0.011 & 0.264 \\
\hline
\end{tabular}

Table 2. Random intercepts by text.

\begin{tabular}{lrrrr}
\hline Genre & Intercept & Tokens & $\mathbf{n} / \mathbf{n}+\mathbf{y}$ & $\begin{array}{r}\text { Centered factor } \\
\text { weight }\end{array}$ \\
\hline Biography & 0.745 & 3571 & 0.059 & 0.675 \\
Science & 0.601 & 310 & 0.155 & 0.642 \\
Law & 0.284 & 312 & 0.141 & 0.567 \\
History & 0.252 & 1262 & 0.075 & 0.559 \\
Narrative-religious & -0.001 & 3485 & 0.048 & 0.496 \\
Fiction & -0.012 & 14032 & 0.023 & 0.493 \\
Religious-saga & -0.141 & 1393 & 0.041 & 0.461 \\
Religious & -0.174 & 2370 & 0.015 & 0.453 \\
Saga & -0.233 & 14493 & 0.038 & 0.438 \\
Sermons & -0.485 & 4732 & 0.016 & 0.377 \\
Bible & -0.659 & 2689 & 0.007 & 0.337 \\
\hline
\end{tabular}

Table 3. Random intercepts by genre. 
The overall $\mathrm{R}^{2}$ of the regression model, a measure of its goodness of fit to the data, is 0.449 , indicating that about $44.9 \%$ of the data can be predicted using the independent variables we have selected. Of this, 0.104 comes from the random factors of text and genre. No obvious pattern emerges from table 2. The texts that favor null subjects the most (given other factors) are the First Grammatical Treatise, the oldest text in the corpus (dated ca. 1150), and Pétur Gunnarsson's novel Sagan öll, one of the most recent (1985).

As for genre, it appears from table 3 that scientific texts are likely to contain more null subjects, but since the First Grammatical Treatise and Jónas Hallgrímsson's Um eðli og uppruna jarðarinnar are the only scientific texts in the corpus, this result has to be taken with a grain of salt. Religious texts of all types (including sermons, Bible translations, and religious sagas) seem to disfavor null subjects, with Bible texts being the least favorable environment of all. This casts doubt on the potential argument that null subjects in early Icelandic are an artificial feature present in texts solely because of Classical influence: If it were so, one would predict Bible translations to have an extremely high incidence of null subjects, contrary to fact. ${ }^{8}$

\subsection{Clausal Distribution.}

The clausal distribution of null subjects has been a central concern in both traditional and recent accounts of the null subject phenomenon. As illustrated by the examples in 2 below, null subjects occur in all clause

\footnotetext{
${ }^{8}$ As one reviewer points out, it is less than ideal that some genres are underrepresented in the IcePaHC corpus, or only represented for certain periods. In addition to the fact that there are only two scientific texts, it could be added that there is only one legal text (Grágás), and that Bible texts are not represented after 1540 . We are aware that the uneven representation of genres may potentially influence our results, but there is, in practice, not much that can be done to amend the situation. To manually annotate the number of new texts required to even out the differences would not be feasible in the context of a study like ours. In our view, the advantages of having an annotated corpus outweigh the problems related to genre representation.
} 
types in the investigated material, whether main, $2 \mathrm{a}$, conjunct, $2 \mathrm{~b}$, or subordinate, $2 \mathrm{c} .{ }^{9}$

(2) a. [pro] Snýr síðan inn í stofuna [pro] turns then into in house-ACC.DEF

'He then entered the house.'

(1275.MORKIN.NAR-HIS,.186)

b. Ásjóna hans var líkari svartri jörðu

face his was more.like black earth

en mannligum yfirlitum.

than human skin

Og [pro] bar eina digra stöng í hendi af járni gerða. and [pro] carried a huge pole in hand of iron made

'His face was more similar to black earth than human skin, and he carried in his hand a huge pole made of iron.'

(1450.ECTORSSAGA.NAR-SAG,.214)

c. Var Jóan fyr pessa sök af lífi tekinn, was John for this reason from life taken

og var fólgið höfuð hans langa ævi

and was hidden head his long time

uns hann sagði sjálfur hvar [pro] var.

until he said self where [pro] was

'John was executed for this reason, and his head was hidden for a long time, until he himself said where it was.'

(1150.HOMILIUBOK.RL-SER,.255)

\footnotetext{
${ }^{9}$ Note again that cases of conjunction reduction are not included in our data. Thus, null subjects occurring in conjunct clauses are not coreferent with the subject of the immediately preceding main clause, as illustrated in $2 \mathrm{~b}$.
} 
In section 1, it was hypothesized on the basis of the distribution of null subjects in other early Northwest Germanic languages, that null subjects will be rarer in subordinate clauses than in main clauses. However, while no previous large-scale quantitative investigation of the clausal distribution of null subjects in early Icelandic has been carried out, there is reason to believe that Icelandic may provide a counterpoint to its early Germanic sisters: Sigurðsson (1993:262) says that null subjects were "frequent in subordinate clauses." Similarly, Walkden (2014:166-168) finds that null subjects are actually more frequent in subordinate than in main clauses in four texts from the 12th and 13th centuries.

We are now in a position to provide extensive quantified data on the clausal distribution of null subjects in the history of Icelandic. For this purpose, table 4 gives aggregate frequencies for the distribution of overt and null subjects according to clause type in the entire IcePaHC corpus.

\begin{tabular}{lrrrr}
\hline & Overt & Null & Total & $\%$ null \\
\hline Main & 16839 & 340 & 17179 & $2.0 \%$ \\
Conjunct & 7956 & 461 & 8417 & $5.5 \%$ \\
Subordinate & 22226 & 827 & 23053 & $3.6 \%$ \\
\hline & 47021 & 1628 & 48649 & $3.3 \%$ \\
\hline
\end{tabular}

Table 4. Overt versus null subjects according to clause type.

Table 4 shows that null subjects are most frequent in conjunct clauses, at a frequency of $5.5 \%$ of the total number of pronominal subjects in such clauses. The frequency for null subjects in main clauses is notably lower, at $2 \%$. It is also notable that null subjects are comparatively frequent in subordinate clauses, at a relative frequency of $3.6 \%$. If frequencies for main and conjunct clauses are collapsed, it can be observed that the distribution of null subjects is remarkably similar across main and subordinate clauses: In the entire period under investigation, $3.1 \%$ of all subjects in main clauses are null. Thus, null subjects are slightly more frequent in subordinate than in main clauses across the investigated period. This result provides substantial quantitative corroboration of Sigurðsson's (1993) assertion that null subjects are frequent in subordinate clauses in Old Icelandic, at least if it is acknowledged that null 
subjects are rare in all clause types. It also mirrors and extends the quantitative findings of Walkden (2014).

\subsection{Person and Number.}

The person and number features of the omitted argument have also constituted factors of central importance in both traditional and modern accounts of the null subject phenomenon. In early Principles and Parameters theorizing, as well as in traditional grammar, the possibility of null arguments was related in large part to the concomitant presence of rich, morphologically instantiated, verbal agreement (see traditional works, such as, for example, Bopp 1820 and Ohlander 1943, and works couched in early generative theory, such as Taraldsen 1978, Chomsky 1982, Rizzi 1982, 1986, and Jaeggli \& Safir 1989).

Although it has proven difficult to formalize, this connection is also considered relevant by authors working within the current Minimalist Program (see, for instance, Platzack 1996, Holmberg 2010, and van Gelderen 2013). The connection between rich verbal agreement and null arguments in early Scandinavian languages is assumed by, for example, Falk \& Torp (1900), Falk (1993), and Holmberg \& Platzack (1995). Since both early and present-day Icelandic encode a relatively wide range of person and number features, and since there has been remarkably little loss of verbal inflections in the course of the history of the language (Sigurðsson 1993:249), it might be expected that null subjects should be able to occur relatively freely with 1 st, 2 nd, or 3 rd person reference, whether singular or plural. In terms of existential evidence, this expectation is borne out by the IcePaHC data, as illustrated in the examples below, which show a 1st person singular null subject in $3 \mathrm{a}$, and 2nd person singular and 3rd person plural null subjects in $3 b, c$.

(3) a. "Ekki em [pro] pví mjög vanur" svarar konungur [...]. not am [pro] that well accustomed replies king "II am not well accustomed to that," replied the king [...].'

(1275.MORKIN.NAR-HIS,.1596)

b. og [...] bið ég pig að [pro] sért örugg and $[\ldots]$ ask I you-ACC that $[$ pro] be-2SG.SBV true 
og staðföst í pinni trú

and steadfast in your faith

'and [...] I ask you that you should be true and steadfast in your faith'

(1525.GEORGIUS.NAR-REL,.757)

c. Og einn dag er menn voru úti staddir pá sá and one day when men were outside present then saw

peir menn fara að bænum marga og [pro] riðu. they men come to farm many and [pro] rode

'And one day when the men were outside, they saw many men approach the farm, and they were riding.'

(1275.MORKIN.NAR-HIS,.1530)

However, previous research indicates that null subjects were not freely distributed across persons. Even at an early stage, as noted above, Nygaard (1894:4-5) claimed that omission of 1st and 2nd person pronouns was very rare in Old Norse, except in imperative clauses and in conjunction reduction contexts (see also Nygaard 1906:8-9 and Sigurðsson 1993:253). Consequently, it may be expected that null subjects in early Icelandic also primarily have 3rd person reference. Table 5 presents the results of a quantitative investigation of the person and number features of the pronominal subjects in the IcePaHC.

\begin{tabular}{lrrrr}
\hline & Overt & Null & Total & \% null \\
\hline 1SG & 9715 & 108 & 9823 & $1.1 \%$ \\
$1 \mathrm{PL}$ & 2909 & 59 & 2968 & $2.0 \%$ \\
2SG & 5204 & 31 & 5235 & $0.6 \%$ \\
2PL & 358 & 10 & 368 & $2.7 \%$ \\
$3 \mathrm{SG}$ & 22086 & 1064 & 23150 & $4.6 \%$ \\
$3 \mathrm{PL}$ & 6749 & 356 & 7105 & $5.0 \%$ \\
\hline & 47021 & 1628 & 48649 & $3.3 \%$ \\
\hline
\end{tabular}

Table 5. Overt versus null subjects according to person and number. 
The table shows that 3rd person subject pronouns indeed are more frequently null than 1 st and 2 nd person pronouns. Third person singular pronouns are null in $4.6 \%$ of the cases, and 3rd person plural pronouns are null in $5 \%$ of the cases. The corresponding frequencies for the $1 \mathrm{st}$ person are $1.1 \%$ (singular) and 2\% (plural), whereas the frequencies for the 2 nd person are $0.6 \%$ (singular) and $2.7 \%$ (plural). There is a substantial effect for "person" in the regression analysis. As illustrated in table 6 below, 3rd person can be observed to favor nullness across the entire dataset. The table indicates that 3rd person pronouns are most likely to be realized as null, whereas 1 st and 2 nd person pronouns are less likely to be. This finding offers robust statistical support favoring the intuition that pro-drop is largely restricted to the 3rd person in early Icelandic.

\begin{tabular}{lrrrr}
\hline Factor & Log odds & Tokens & $\mathbf{n} / \mathbf{n}+\mathbf{y}$ & $\begin{array}{r}\text { Centered factor } \\
\text { weight }\end{array}$ \\
\hline 3 & 4.472 & 30255 & 0.047 & 0.989 \\
1 & -1.998 & 12791 & 0.013 & 0.119 \\
2 & -2.475 & 5603 & 0.007 & 0.078 \\
\hline
\end{tabular}

Table 6. Results of a one-level regression analysis for the predictor person.

A striking feature of the dataset is that the person distribution of the null arguments shifts substantially in the history of Icelandic: 3rd person null arguments become rarer, while 1st and 2nd person null arguments become more frequent. This is illustrated in figures 2 and 3 below. The interaction between "person" and "year" is highly significant $(p<0.0001)$. Table 7 shows that with each passing year, 1st and 2 nd person subjects are slightly more likely to be null, and 3rd person subjects are slightly less likely to be. This supports the view that the licensing mechanisms for null arguments in Icelandic have changed (see section 4.2). 


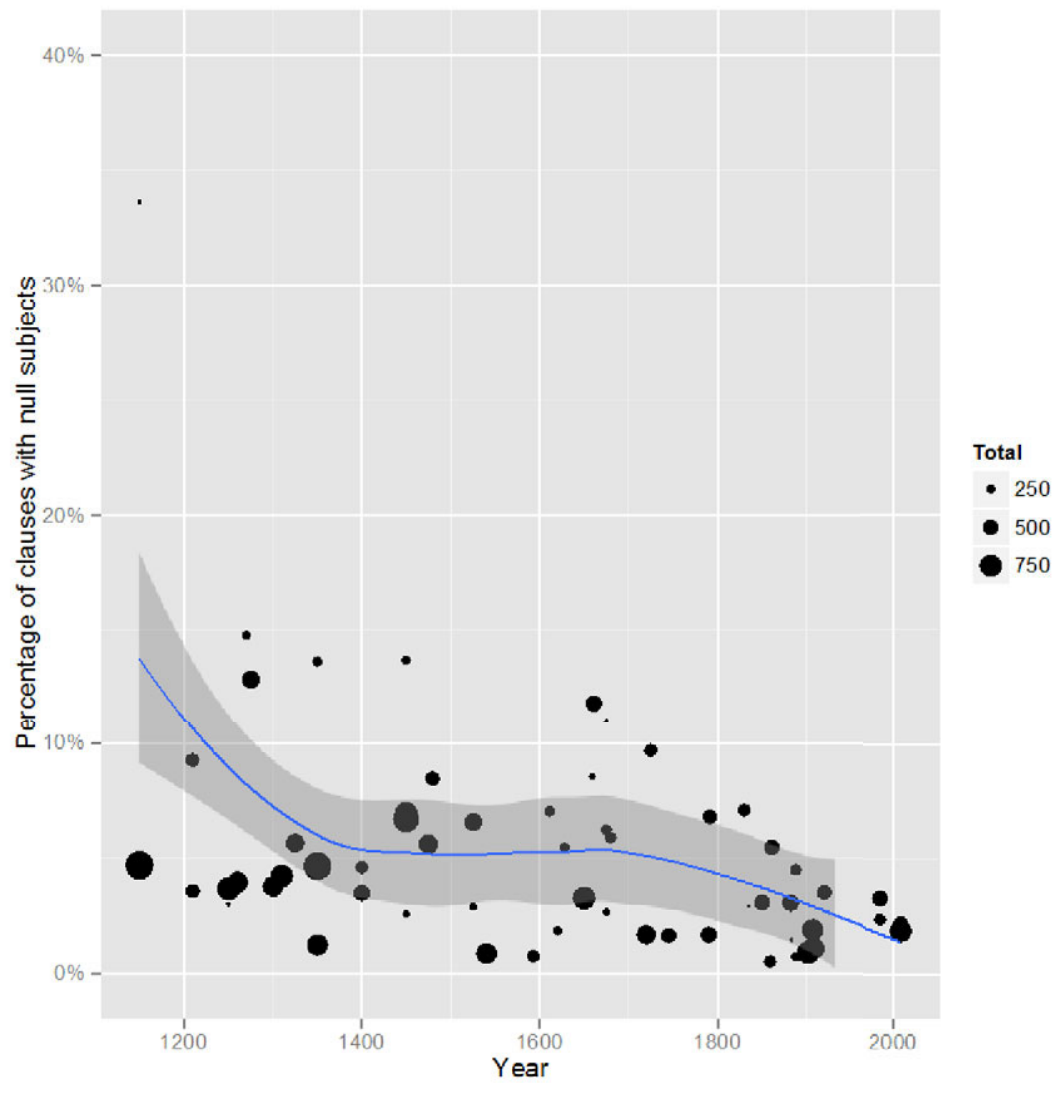

Figure 2. 3rd person null subjects by text across time. 


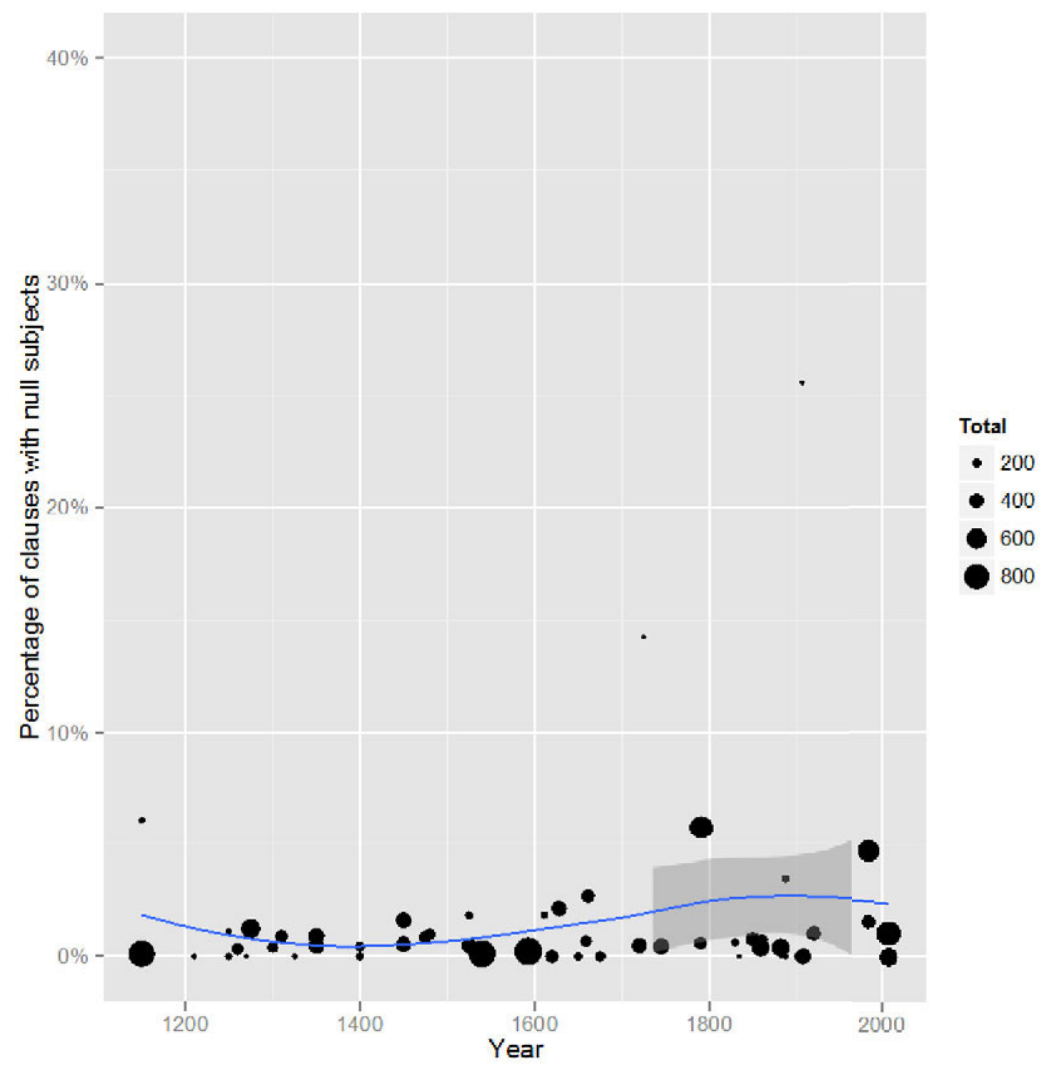

Figure 3. 1st and 2nd person null subjects by text across time.

\begin{tabular}{lr}
\hline Factor & Log odds \\
\hline $1:+1$ & 0.001 \\
$2:+1$ & 0.001 \\
$3:+1$ & -0.002 \\
\hline
\end{tabular}

Table 7. Interaction between the predictors person and year.

We also note that the apparent modest conditioning effect of number, with log odds values of 0.063 for plural and -0.063 for singular, does not emerge as significant at the 0.01 level $(\mathrm{p}=0.0444)$. 


\subsection{Icelandic Null Subjects According to Period.}

Upon scrutiny of table 1 and figure 1, it may be observed that relative frequencies for null subjects decline somewhat over time, although the change is by no means dramatic. In fact, once the interactions of "year" with "person" and "type" are accounted for (see tables 7 and 10), there is no significant effect of "year" as a predictor $(\mathrm{p}=0.134)$. That is, the absolute decrease in proportion of null subjects over time is not considered to be a change distinguishable from noise.

In light of this, and also in light of Hjartardóttir's (1987) assertion that null subjects survive until the 19th century, it would appear a fruitful venture to quantitatively chart the process by which Icelandic null subjects gave way to the topic drop of today (see section 4.1). Thus, the diachronic development of nonovert subject pronouns in the IcePaHC is highlighted in table 8 . The table gives frequencies for overt versus null subjects aggregated into periods comprising roughly 100 years. The periodization-like any periodization - is largely arbitrary, and is presented only for ease of visualization of the trends: We do not base any substantive claim on this division of texts. Each period contains between 8 and 11 texts, with the exception of the earliest period, for which only 6 texts were available. Within the periods, the texts are for the most part well spread out rather than clustered - though of course the dates given for many texts, especially in the earlier periods, are approximate rather than exact, as the precise date of composition is often not known. Readers interested in a more detailed breakdown of the figures given here can consult table 1 and figure 1 .

\begin{tabular}{lrrrr}
\hline Period & Overt & Null & Total & \% null \\
\hline $1150-1250$ & 4060 & 190 & 4250 & $4.5 \%$ \\
$1260-1350$ & 8132 & 379 & 8511 & $4.5 \%$ \\
$1400-1480$ & 6640 & 313 & 6953 & $4.5 \%$ \\
$1525-1630$ & 6800 & 126 & 6926 & $1.8 \%$ \\
$1650-1745$ & 5963 & 254 & 6217 & $4.1 \%$ \\
$1790-1888$ & 7290 & 198 & 7488 & $2.6 \%$ \\
$1902-2008$ & 8136 & 168 & 8304 & $2.0 \%$ \\
\hline Total & 47021 & 1628 & 48649 & $3.3 \%$ \\
\hline
\end{tabular}

Table 8 . Overt versus null subjects by period. 
As the table shows, relative frequencies for null subjects remain relatively stable at below $5 \%$ but above $1.5 \%$ of all pronominal subjects in all seven periods. There is a decline from $4.5 \%$ to $2 \%$ from the earliest to the latest period. It may be noted that frequencies for null subjects remain stable at $4.5 \%$ during the three earliest periods, covering ca. 330 years. There is a comparatively sharp drop to $1.8 \%$ in the next period, 1525-1630. This decline is followed by a similarly sharp increase to $4.1 \%$ in the immediately following period covering $1650-1745$. The two final periods under investigation, 1790-1888 and 1902-2008, display lower frequencies than those observed in the earlier periods, at $2.6 \%$ and $2 \%$, respectively. However, it should be kept in mind that, aside from certain texts, the phenomenon is actually quite rare at all stages of Icelandic.

Hjartardóttir (1987) and Sigurðsson (1993) are able to claim that Icelandic lost its null subject property in the 19th century, although they acknowledge that modern Icelandic has topic drop. Tables 1 and 8 show, however, that the relative frequencies for null subjects in the 20th century - at which stage Icelandic is not a null subject language - are essentially the same as those in the period covering the late 18th and the 19th centuries. Thus, since the difference between these periods is negligible, and since there are no significant diachronic differences in the frequencies for nonovert subjects in the entire period investigated, we would like to argue that Icelandic permits null arguments throughout its history but shifts to a fundamentally different licensing mechanism at the turn of the 20th century. We address this issue in the immediately following section 4 .

\section{Licensing Mechanisms.}

\subsection{One or Two Licensing Mechanisms in Early Icelandic?}

Many modern Germanic non-null-subject languages, including Icelandic, allow dropping of constituents in main clauses when Spec CP is empty, that is, in verb-initial (V1) main clauses, in certain registers (see, for example, Ross 1982 and Trutkowski 2011 on German; Haegeman 1990 and Weir 2012 on English; de Korte 2008 on Dutch; Mörnsjö 2002 and Wendt 2006 on Swedish; Pouplier 2003 and Thráinsson 2007:277 on Icelandic; and Stjernholm 2008 and Nygård 2013 on Norwegian). This phenomenon is often referred to as TOPIC DROP (alternatively: diary drop, pronoun zap, discourse ellipsis), and it is commonly assumed to be 
fundamentally different from pro-drop, due to the positional and stylistic restrictions on its distribution (see Sigurðsson 2011 for a unified account, though). ${ }^{10}$ Modern Icelandic topic drop is illustrated in example 4 (from Thráinsson 2007: 477). ${ }^{11}$

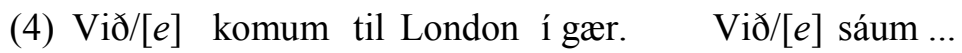
we $/[e]$ came to London yesterday we $/[e]$ saw ... 'Came to London yesterday. Saw ...'

Sigurðsson (1993) advocates a distinction between topic drop (on his analysis, a null topic operator binding a variable) and genuine pro-drop in Old Icelandic. On such an analysis, there would be two licensing mechanisms for null subjects, of which only one was lost during the transition into modern Icelandic. According to Sigurðsson (1993), prodrop and topic drop are found in different positions: Topic drop occurs in V1 main clauses, while pro-drop is restricted to subordinate clauses and V2 main clauses. One of Sigurðsson's arguments in favor of the distinction is related to an alleged difference in terms of antecedent relations: Sigurðsson (1993:251-252) claims that pro always requires an overt DP antecedent (or NP antecedent, in his terms) in the preceding discourse, whereas dropped topics in V1 main clauses can occur without an overt DP antecedent. On Sigurðsson's account, antecedentless topic drop is possible because dropped topics can be identified by "free coindexing at LF with a construed, clause-external topic" (Sigurðsson 1993:260). The antecedent of a dropped topic can be split, partial, or not present at all

\footnotetext{
${ }^{10}$ Note that, from the perspective of information structure, the term topic drop only entails an intuitive notion of topicality; the main point is that dropping is restricted to the sentence-initial position. We remain agnostic with regard to the formal analysis of topic drop. Traditionally, topic drop has often been analyzed as an empty operator binding a variable (for example, Haegeman 1990 and Sigurðsson 1993), but it has also been considered a PF phenomenon (for example, Weir 2012). Nygård (2013) presents an analysis in which syntactic and semantic restrictions are combined.

${ }^{11}$ Certain modern Icelandic conjunct clauses have been analyzed as involving pro (Pouplier 2003). We abstract away from that and maintain that modern Icelandic is a non-pro-drop language. See also Rögnvaldsson 1990 and Bresnan \& Thráinsson 1990 on coordination in modern Icelandic.
} 
(Sigurðsson 1993:252); in the latter case, it must be inferred from the context.

In the more recent works of Sigurðsson (2011), Håkansson (2013), and Walkden (2014), only one licensing mechanism is assumed. This has theoretical advantages: If one licensing mechanism can account for all null subjects, it is not desirable to postulate two. However, none of the three works discusses empirical reasons for treating early Icelandic null subjects in a unified way.

The IcePaHC data reveal that counterexamples to Sigurðsson's (1993) generalization about antecedent relations can be found. In other words, null subjects that do not have a DP antecedent do sometimes occur in contexts other than V1 main clauses. This is not a frequent phenomenon, but we have found the examples in 5-8, which we discuss in some detail. The context of example 5 is a fight. Jökull has just attacked a man called Gunnbjörn when Finnbogi enters the scene.

(5) Og í pví kom Finnbogi að og leggur til Jökuls and in that came Finnbogi to and lays to Jökull

svo að pegar stóð [pro] í beini.

so that soon stood [pro] in bone

'And in that moment Finnbogi came and struck Jökull so that his weapon was stuck in Jökull's bone.'

(1350.FINNBOGI.NAR-SAG,663.2194)

Finnbogi's weapon is not mentioned in the previous discourse but must be inferred from the extralinguistic context.

Example 6 is from the New Testament, more precisely from the scene in which Jesus has been crucified and is offered vinegar to drink. Jesus utters the words cited in 6.

(6) En pá Jesús hafði edik ið til sín tekið, and when Jesus had vinegar the to him-REFL taken,

sagði hann: Fullkomnað er [pro].

said he: complete is [pro] 
'And when Jesus had drunk the vinegar, he said: "It is complete."”

(1540.NTJOHN.REL-BIB,229.1531)

The null subject must refer to Jesus' mission on Earth, which is not explicitly mentioned in the previous discourse.

In example 7, the main character, Illugi, suspects that a treasure might be hidden in the vicinity, and he asks a woman, Kaðlin, about this. Kaðlin responds as follows:

$\begin{array}{ll}\text { Kallaður } & \text { er [pro] hér Óblauðshaugur, } \\ \text { called-SG.MASC.NOM is }[\text { pro] here Óblauðshaugur-SG.MASC.NOM }\end{array}$

er sagt hefir verið um, að í honum mundi

COMP said has been about COMP in it-SG.MASC.DAT might

fólgið mikið fé og vopn.

hidden much goods and weapons

'This mound is called Óblauðshaugur, and it is said about it that much goods and weapons may be hidden there.'

(1650.ILLUGI.NAR-SAG,.1521)

The mound in 7 is not previously mentioned, and thus it must be inferred from the context. A potential objection is that the null subject could be interpreted as nonreferential; an equivalent Modern Norwegian sentence may optionally be construed with a nonreferential det 'that'. However, such a reading of 7 would be problematic: In early Icelandic, nonreferential null subjects trigger 3rd person singular neuter agreement on participles and adjectives (see, for example, Nygaard 1906:16), but the participle kallaður is masculine and agrees with haugr 'mound'. The example in 8 is about a king who hosts a big Yule party.

(8) Kóngur hélt jóla bod mikið, og var svo fjölmennt king held Yule party big and was so many.people-ADJ

að [pro] miklu jók við pað sem áður var vant that $[$ pro $]$ much exceeded to that which before was used.to 
'The king hosted a big Yule party, and the number of guests was so high that it greatly exceeded what they were used to.'

(1480.JARLMANN.NAR-SAG,.813)

The null subject is most naturally interpreted as referring to the number of people present at the Yule party. The group of people is not explicitly mentioned as a referent, but must be inferred from the adjective fjölmennt 'with many people'.

The context of example 9 is the appointment of pope Gregory X. The null subject refers to the entity that has been páfalaust 'without pope', which is most naturally interpreted as the papacy. The papacy is not explicitly mentioned in the previous context but must rather be inferred.

(9) Á pessu ári var vígður Gregoríus páfi $X$ en áđur in this year was ordained Gregory pope 10 and before

hafði [pro] páfalaust verið nær fimm vetur. had [pro] without.pope-SG.NEUT been nearly five winters

'In this year Pope Gregory X was ordained, and before that, the papacy had been without a pope for nearly five years.'

(1325.ARNI.NAR-SAG,.267)

Another issue, not mentioned by Sigurosson (1993), is the fact that the referent of a null subject is not necessarily a person or a thing. Sometimes the referent is a situation or a proposition, and referents of this type are often represented as CPs rather than DPs. Sometimes there is a CP in the preceding discourse that directly corresponds to the null subject. These cases are not necessarily problematic for Sigurðsson's generalization: pro has an antecedent, though it is a CP rather than a DP. In other cases, the referent of the null subject does not directly correspond to any $\mathrm{CP}$ in the preceding context. Arguably, such referents also require inference by the speaker. The null subject is thus antecedentless. See the subordinate clause in 10a and the last main clause in $10 \mathrm{~b}$.

(10)a. pá heyra peir barns grát og vissu eigi then hear they children's cry and know not 
hví [pro] sæta mundi.

why [pro] come.about could

'Then they heard the crying of children, and they didn't understand why this could be.'

(1260.JOMSVIKINGAR.NAR-SAG,.31)

b. "pú hefir mikið tungubragð," segir kóngur, you have great tongue.cleverness says king

“en á morgin áđur sól er í lands suðri skal eg but in morning before sun is in land south shall I

finna yður á vígvelli. Og gjöra yður pann úrskurð find you on battlefield and do you that judgment

að pér skuluð aldri síðan krefja lands né kvenna. that you shall never since demand land nor women

Hefi eg bæði heyrt stór orð og séð stóra menn. have I both heard great words and seen great men

Og hræðunst eg aldri heiðnar mannsskræfur." and fear I never heathen cowards

"Vel er [pro]," sagði Landres. well is [pro] said Landres

''You are very eloquent,' the king said, 'but tomorrow before the sun is up I shall find you on the battlefield and make sure that you shall never again demand land nor women. I have heard great words and seen great men, and I never fear heathen cowards.' 'That is fine', Landres said."

(1480.JARLMANN.NAR-SAG,.461-465)

On the most obvious interpretation of $10 \mathrm{a}$, the null subject refers to the fact that there appeared to be children crying. If the whole preceding $\mathrm{CP}$ were the antecedent, it would imply that the subject was the fact that 
people heard children cry. In $10 \mathrm{~b}$, the null subject is, on the most obvious interpretation, referring to the whole situation described in the preceding discourse, not just the last sentence. There is, in other words, not a single $\mathrm{CP}$ antecedent. To sum up, the data in 5-10 seem to show that there is no absolute rule against antecedentless null subjects in contexts other than V1 main clauses. ${ }^{12}$ We discuss the implications of this below.

${ }^{12}$ One reviewer disagrees with our interpretation of the data:

[...] none of these examples contain a clearly referential null subject. Instead, the nulls in these examples have an impersonal arbitrary reading, 'something unspecified', or even a vague reading that comes close to being expletive. In addition, the constructions in some of these examples get semi-idiomatic readings, possible to an extent in the modern language.

To start with the first point, it is not clear to us how the subjects in 5-10 can be considered "impersonal arbitrary," "unspecified," or "close to being expletive." The predicates in question do not seem to be of the type that can take expletive subjects. Example 7 is an exception, but as argued above, morphological evidence speaks against an expletive reading in this case. As for impersonal, arbitrary readings, we have consulted Sigurðsson \& Egerland 2009, which is probably the most relevant in-depth study of the phenomenon. Sigurðsson \& Egerland 2009:158 distinguish between three types of impersonal subjects: generic ones, such as generic English you, arbitrary ones, such as arbitrary English they, and specific ones, "often referring to the speaker or a group including the speaker." We cannot see that any of these readings apply in examples 5-10. We do acknowledge that it sometimes can be very difficult to draw the line between referential and impersonal/expletive/arbitrary subjects, and that there may be cases in which the IcePaHC annotation is not accurate. However, since there are no generally agreed-upon and replicable criteria for deciding what is referential and what is not, we have decided, for simplicity's sake, to base our analysis on the choices made by the annotators. To us, the examples in 5-10 do not seem too problematic.

Regarding the reviewer's second point, "semi-idiomatic readings," Nygaard (1906:12) notes that antecedentless null subjects in Old Norse tend to occur in contexts relating to hewing, shooting etc., as in 5, and with verbs meaning 'be called', as in 7 . We take it that this is what the reviewer means by "semi-idiomatic." However, the fact that antecedentless null subjects occur particularly frequently in these semantic contexts does not automatically imply that one should expect the null subjects in 5 and 7 to be exempt from syntactic 


\subsection{Shift from Pro-drop to Topic Drop.}

It was mentioned in section 3.5 that the decline in raw numbers of null subjects over the 850-year period under investigation is not statistically significant: The predictor "year" had a nonsignificant value on its own. Furthermore, table 8 shows that there is little to distinguish relative frequencies for null subjects in the two periods $1790-1888$ and 19022008 from one another, as the periods have frequencies for null subjects of $2.6 \%$ and $2 \%$, respectively. As recalled, Hjartardóttir (1987) claims that Icelandic licensed null subjects until the end of the 19th century. An obvious way to reconcile this claim and our empirical finding with the standard view that modern Icelandic generally requires overt subjects is to argue that Icelandic changed the mechanism by which nonovert subjects could be licensed. By virtue of this change it transitioned from a system with restricted pro-drop to one where only topic drop is licit. We argue that our data indicate that the shift to what we refer to as the "modern" stage-where pro-drop yields to topic drop-arises in Icelandic in the early 20th century, in agreement with Hjartardóttir's (1987) earlier study.

Tables 9-12 provide empirical support for this argument. Consider first table 9, which gives relative frequencies for null subjects according to period, clause type, and initial/noninitial position of the finite verb. Distinction is made between verb-initial (MainV1) and non-verb-initial main clauses (MainNonV1), verb-initial (ConV1) and non-verb-initial conjunct clauses (ConNonV1), and subordinate clauses. We abstract away from the possibility of fronting constituents to Spec $\mathrm{CP}$ in subordinate clauses, hence no distinction as to verb position is made for this clause type.

rules applying elsewhere. An argument along those lines would have been convincing if antecedentless null subjects in non-V1 contexts were restricted to "semi-idiomatic" contexts, but the reviewer's comment only concerns some of the examples.

The reviewer mentions that example 7 would be possible in "educated" modern Icelandic, which otherwise does not allow null subjects. This clearly supports the argument that 7 is idiomatic at the modern Icelandic stage, but it does not necessarily follow that it was idiomatic in the middle of the 17th century. 


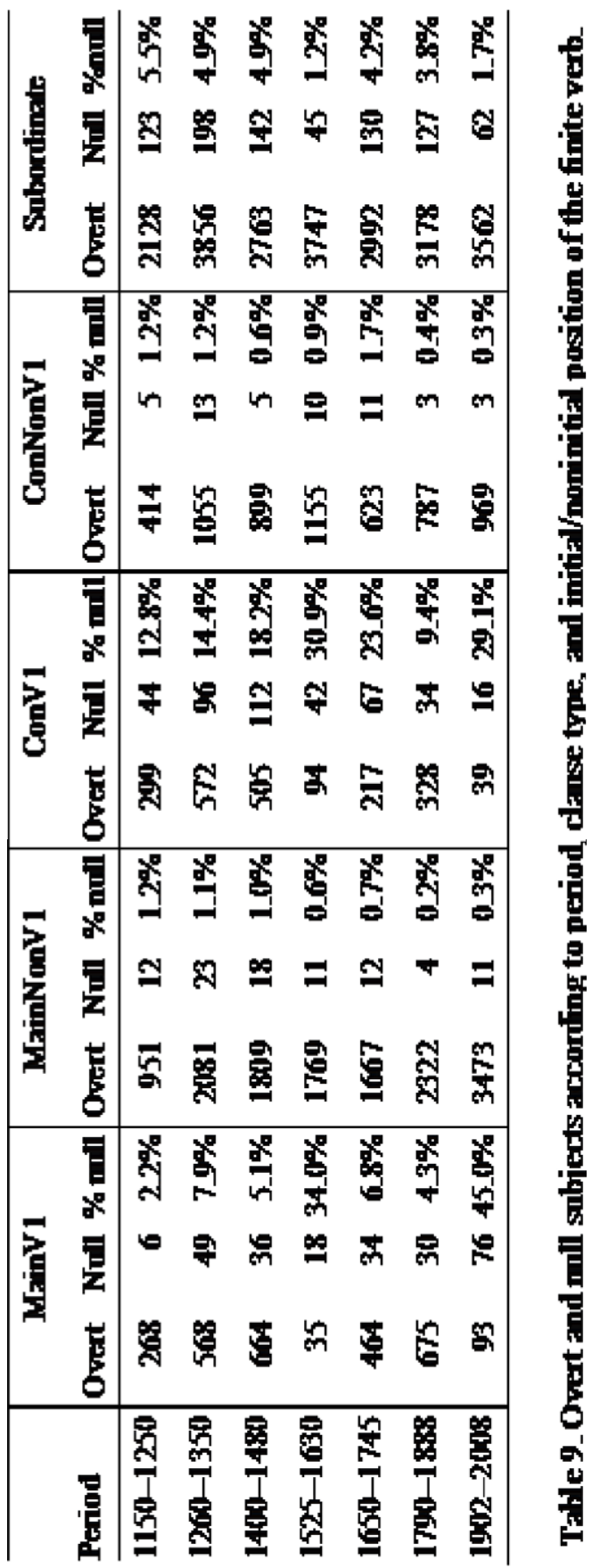


First, our data show that there is a clear decline of null subjects in subordinate clauses in the period 1902-2008. Subordinate clauses are a context in which topic drop is not licit; we take the decline of omitted subjects in subordinate clauses to indicate that pro-drop is disappearing and topic drop is taking over. Second, and relatedly, observe that there is a clear rise of omitted subjects in nonconjunct V1 main clauses in the period 1902-2008, as compared to previous periods. ${ }^{13}$ We take the rise of omitted subjects in V1 main clauses to be evidence that the new licensing mechanism and the new pragmatic function of topic drop is gaining ground.

Finally, consistently with our hypothesis, null subjects in non-V1 main clauses (both conjunct and nonconjunct) are very infrequent in the period 1902-2008. This is another context in which topic drop is ruled out. Figure 4 illustrates the decline of null subjects in the three contexts where it is illicit under a standard topic drop analysis: non-V1 main and conjoined clauses, and subordinate clauses in general. By the end of the 20th century, the frequency of null subjects in these contexts is minuscule. ${ }^{14}$ The interaction between "type" and "year" is clearly significant in the regression analysis $(\mathrm{p}<0.0001$; see table 10$) .{ }^{15}$

\footnotetext{
${ }^{13}$ The high relative frequency of null subjects in V1 main clauses between 1525 and 1630 is a puzzling fact for which we have no explanation. Given that the overall number of relevant V1 main clauses for this period is particularly low (only 53, of which 18 have null subjects), this may simply be a statistical outlier that is an artifact of the method and of our periodization. Even more striking is the relative frequency of null subjects in V1 main clauses in the most recent period, 1902-2008. Of the 76 null examples here, 35 are from a single text, Sagan öll by Pétur Gunnarsson. A reviewer observes that this author's work is characterized stylistically by frequent use of non-overtly-conjoined clauses with a null topic; hence, some or all of these examples may be better analyzed as involving conjunction reduction. The same reviewer also makes the suggestion that the apparent increase in topic drop over the 20th century is simply a consequence of the colloquialization of written language rather than the expression of an actual grammatical change.

${ }^{14}$ The few such examples that we find in these late texts can all be analyzed either as not involving a referential null subject or as not, in fact, instantiating a problematic structure. Example $\mathrm{i}$ is retrieved by our queries as a verb-second structure, but the interjection $j u$ should be analyzed as extraclausal, in which case this is nothing more than a normal case of 1st person topic drop.
} 


\begin{tabular}{lr}
\hline Factor & Log odds \\
\hline MainV1:+1 & 0.003 \\
ConV1: +1 & 0.001 \\
ConNonV1: +1 & -0.001 \\
Sub: +1 & -0.001 \\
MainNonV1: +1 & -0.002 \\
\hline
\end{tabular}

Table 10. Interaction between the predictors type and year.

\begin{tabular}{lrrrr}
\hline Factor & Log odds & Tokens & $\mathbf{n} / \mathbf{n}+\mathbf{y}$ & $\begin{array}{r}\text { Centered factor } \\
\text { weight }\end{array}$ \\
\hline Sub & 1.5 & 23053 & 0.036 & 0.818 \\
MainNonV1 & 1.491 & 14163 & 0.006 & 0.816 \\
ConNonV1 & 0.17 & 5952 & 0.008 & 0.542 \\
ConV1 & 0.166 & 2465 & 0.167 & 0.541 \\
MainV1 & -3.326 & 3016 & 0.083 & 0.035 \\
\hline
\end{tabular}

Table 11. Results of a one-level regression analysis for the predictor (clause) type.

(i) Jú $[e]$ ætli pað sé ekki ágætt, segi eg. well $[e]$ think that be not good say I 'Well, I think it is not good, I say.'

As stated above, for the purposes of replicability we have relied on the corpus annotation to find referential null subjects in non-V1 main and conjoined clauses and subordinate clauses. However, the fact that all of the few apparent late examples can be argued to be irrelevant is clearly compatible with the fact that referential null subjects in these contexts are not perceived to be grammatical by native speakers.

${ }^{15}$ Table 11 indicates that, when the interaction between "type" and "year" is taken into account, the non-topic-drop contexts in fact favor null subjects across the dataset. These results are likely to be an artifact of the method, resulting from the strength of the interaction. 


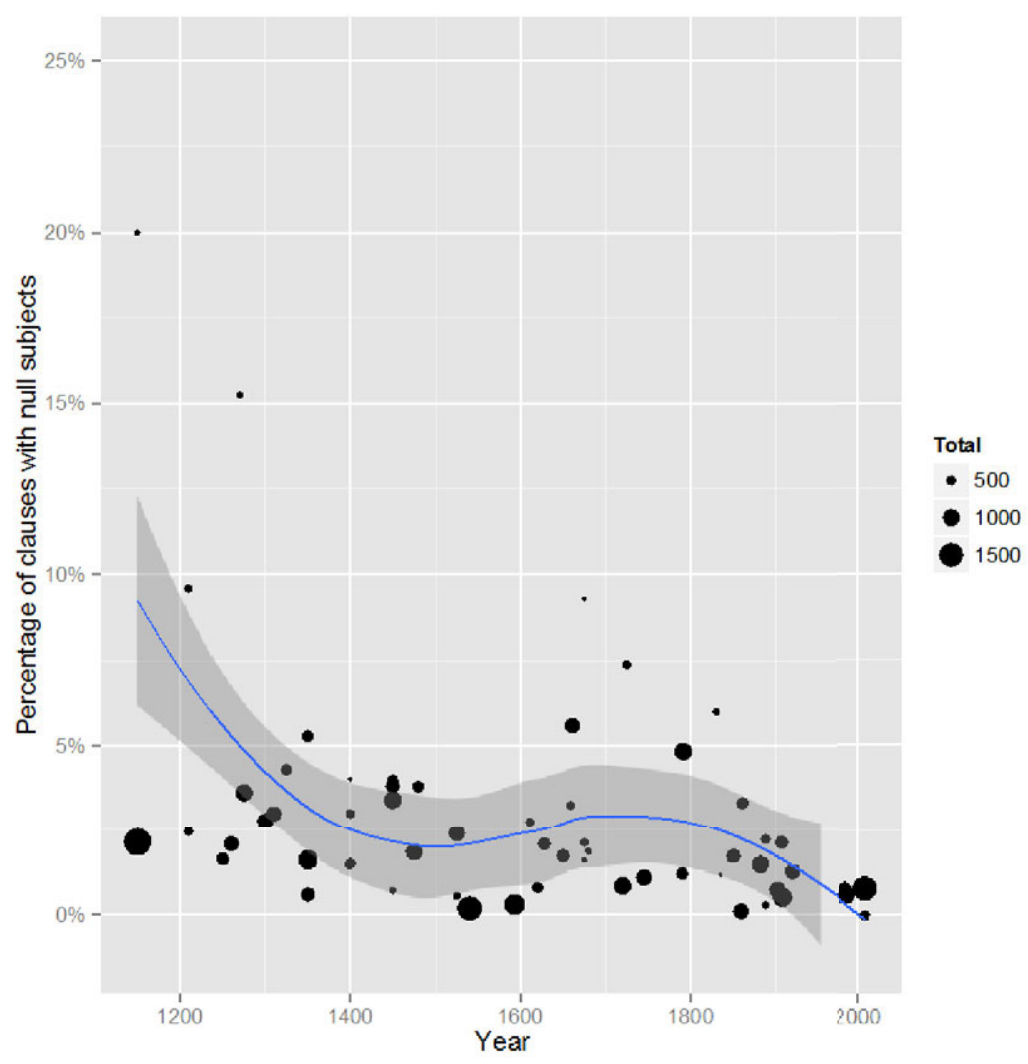

Figure 4. Null subjects in non-topic-drop contexts by text across time.

Evidence based on person features may also support our argument that the modern stage arises in Icelandic in the early 20th century. Modern Germanic topic drop of subjects does not involve any grammatical restrictions on person (Mörnsjö 2002:70, de Korte 2008, Weir 2012), though some studies indicate topic drop of the 1st person to be particularly frequent (Wiggen 1975:88, Faarlund et al. 1997:676, 
Barton 1998). ${ }^{16}$ The situation observed in early Icelandic does not conform to this state of affairs, as shown in table 12 and figures 2 and 3.

\begin{tabular}{l|rrr|rrr|rrr}
\hline & \multicolumn{3}{|c|}{ 1st person } & \multicolumn{3}{|c|}{ 2nd person } & \multicolumn{3}{c}{ 3rd person } \\
Period & Overt & Null & $\%$ null & Overt & Null & $\%$ null & Overt & Null $\%$ null \\
\hline $1150-1250$ & 1018 & 7 & $0.7 \%$ & 227 & 1 & $0.4 \%$ & 2815 & 182 & $6.1 \%$ \\
$1260-1350$ & 1445 & 12 & $0.8 \%$ & 1091 & 7 & $0.6 \%$ & 5596 & 360 & $6.0 \%$ \\
$1400-1480$ & 1373 & 11 & $0.8 \%$ & 990 & 9 & $0.9 \%$ & 4277 & 293 & $6.4 \%$ \\
$1525-1630$ & 2082 & 16 & $0.8 \%$ & 1392 & 3 & $0.2 \%$ & 3326 & 107 & $3.1 \%$ \\
$1650-1745$ & 1645 & 19 & $1.1 \%$ & 373 & 2 & $0.5 \%$ & 3945 & 233 & $5.6 \%$ \\
$1790-1888$ & 2287 & 48 & $2.1 \%$ & 893 & 7 & $0.8 \%$ & 4110 & 143 & $3.4 \%$ \\
$1902-2008$ & 2774 & 54 & $1.9 \%$ & 596 & 12 & $2.0 \%$ & 4766 & 102 & $2.1 \%$ \\
\hline
\end{tabular}

Table 12. Overt and null pronominal subjects according to period and person.

In the early periods, the vast majority of null subjects have 3rd person reference. In contrast, in the latest period, differences between grammatical persons are almost completely leveled. This situation is more in line with what one would expect from a language allowing topic drop. Some examples of modern, omitted subjects with 1st person reference are provided in 11 .

(11) a. [e] Hughreysti hann.

[e] encourage him

'I encourage him.'

(1985.SAGAN.NAR-FIC,.1400)

b. [e] finn pað á pér.

$[e]$ find that for you

'I will find it for you.'

(1985.SAGAN.NAR-FIC,.1278)

Omitted 2nd and 3rd person subjects appear in $12 \mathrm{a}$ and $12 \mathrm{~b}$, respectively.

${ }^{16}$ Some restrictions apply to dropping of 1st and 2nd person objects (Mörnsjö 2002, Sigurðsson 2011 with further references), but that is irrelevant in our context, since we are dealing with subjects only. 
(12) a. [e] Grætur í sæng ina bína.

[e] cry-2SG in bed DET your

'You are crying in your bed.' (1985.SAGAN.NAR-FIC,.1292)

b. [e] fæddist sem barn á pessa jörð.

[e] was.born as child on this earth

'He was born as a child on this earth.'

(1920.ARIN.REL-SER,.818)

To sum up, we have argued that antecedent relations as well as person features suggest a pro-drop analysis for all early Icelandic null subjects. As a reviewer correctly points out, we cannot provide unequivocal evidence that excludes the possibility of an additional licensing mechanism at this stage altogether; perhaps a subset of the early null subjects were derived by topic drop or a predecessor of this phenomenon. In our view, however, the default hypothesis should be that there was one licensing mechanism only, as long as there are no strong empirical arguments to the contrary. Regardless of whether topic drop was available as an additional licensing mechanism already in early Icelandic, clause type and person data suggest a shift to a pure topic drop system at the modern stage.

\subsection{Sketch of a Syntactic Analysis.}

Our aim in this paper is not to arrive at a fully fleshed-out syntactic account of the historical Icelandic facts, especially since there is no consensus on the details of the machinery needed to account for null arguments in current theories of syntax. Rather, we have aimed to present the data and draw the generalizations that any descriptively adequate syntactic analysis of early Icelandic would need to account for. In this section, we present a sketch of one analysis consistent with these generalizations. It should be borne in mind that other theoretical perspectives are possible, and that we leave a fully explanatory account to future research.

In Minimalist syntactic theorizing, null subjects are typically taken to arise from a constellation of interacting factors, in particular the lexical specification of functional categories - such as $\mathrm{C}$ or $\mathrm{T}$ - the structure of pronouns, and third-factor (non-language-specific) considerations (see Biberauer 2008 for an overview). Sigurðsson (2011) argues that referential null arguments are universally available but must be licensed 
by agreement with syntactically-active left-peripheral features, a process he refers to as C/EDGE-LINKING. In the modern Germanic topic-drop languages, null arguments are permitted only when raised into the Cdomain, since in these languages the head $\mathrm{C}$ counts as an intervener and blocks agreement. In contrast, for languages such as Chinese Sigurðsson (2011:297-299) suggests that $C$ does not count as an intervener for the purposes of C/edge-linking, and hence null arguments may occur clauseinternally as well. We assume that in early Icelandic, as in Chinese, the featural make-up of the functional category $\mathrm{C}$ was such that it did not intervene. ${ }^{17}$

In addition, in early Icelandic one observes the person restriction discussed in section 3.4, namely, that 1st and 2nd person subjects are very rarely null. We hypothesize that this is due to differences in the internal structure of the pronouns involved. There are different ways of implementing this, and we remain agnostic as to which one is correct. We could assume that it is simply stipulated lexically whether a particular combination of phi-features may be null in a given language (see Faarlund 2013). Another option is to connect the overtness of 1st and 2nd person subjects with the fact that they realize larger syntactic structures. According to Richards (2015:176), 1st and 2nd person pronouns are always DPs, unlike 3rd person pronouns (see also Déchaine \& Wiltschko 2002). It may be that DPs, unlike smaller structures, are not universally able to be null. Under this account, the core change that has taken place is that $\mathrm{C}$ has become an intervener for the purposes of null argument C/edge-linking in the recorded history of Icelandic. A further change involves the lifting of the requirement that 1 st and 2 nd person subjects be overt.

\section{Null Subjects in Early Northwest Germanic.}

Previous research on null arguments in other early Northwest Germanic languages has shown that these languages exhibit remarkable homogeneity with regard to the conditions under which null arguments may occur. The findings presented in this paper corroborate many of the

\footnotetext{
${ }^{17}$ However, Sigurðsson (2011) notes that this analysis has independent support in Chinese, since there is no verb movement to $\mathrm{C}$ and (in general) no finite complementizer, suggesting that $\mathrm{C}$ may be radically empty in this language. For early Icelandic there is no such independent support.
} 
results of previous research, although some clear differences also emerge. This section provides a cross-Germanic perspective assessing the degree to which our findings for early Icelandic converge with those for its sister languages.

One notable point of such convergence pertains to person features: There is considerable empirical evidence that the person split discussed in section 3.4 applies to the early Northwest Germanic languages as a whole. Several studies have ascertained that early Germanic null subjects predominantly tend to have $3 \mathrm{rd}$ person reference, although 1 st and 2 nd person null subjects are documented. Based on data drawn from Eggenberger's (1961) study of subjectless clauses in Old High German, Axel (2007:314) notes that "[r]eferential null subjects are attested in all persons and numbers," but that "it is only in the third person singular and plural that the null variant is used more frequently than the overt one." A similar pattern holds in a variety of Old English textual genres, whether interlinear glosses (Berndt 1956, van Gelderen 2000, 2013, Walkden forthcoming), prose (Walkden 2013, 2014; Rusten 2013), or poetry (Rusten 2015), though here null subjects in general are much less frequent than in Old High German.

The $3 \mathrm{rd} /$ non-3rd person split is also observed in the Old Saxon Heliand (Walkden 2014), in a selection of Old Swedish texts (Håkansson 2008), in the Old Norwegian Óláfs saga ins helga and in The Old Norwegian Homily Book (Kinn 2015). Walkden (2014) consequently reconstructs a partial null subject property for Proto-Northwest Germanic, which allowed subjects to be null under certain conditions, predominantly in the $3 \mathrm{rd}$ person. ${ }^{18}$ This article provides further comparative evidence suggesting that the 3 rd person had special status in conditioning null subjects in early Germanic.

Moreover, in section 4.1, we argued that Sigurðsson's (1993) distinction between pro-drop and topic drop may be empirically problematic: Contrary to predictions, antecedentless null subjects occurring in non-verb-initial contexts can be found in early Icelandic.

\footnotetext{
${ }^{18}$ Specifically, on his analysis, a subject DP may be null under agreement with a null Aboutness-topic operator in Spec ShiftP. Following Sigurðsson (1993:254), and equating Aboutness-topicality with narrative discourse topicality, Walkden (2014:212) argues that 1 st and 2 nd person referents are unlikely to achieve this type of topicality in discourse, hence their rarity in texts.
} 
Existential evidence from Old English (examples 13a,b) and Old Norwegian (example 13c) suggests that our argument may possibly be extended to these languages as well. ${ }^{19}$

(13) a. Đa dydon hi purh pæs ealdormannes bene then did they through the alderman-GEN prayer

pæt ða deoflu spræcon swa swa heora gewuna wæs that the devils spoke just as their wont was

and sædon pæt pær wære micel gefeoht toweard and said that there was great battle toward

and on ægðre healfe [pro] sceoldon feallan. and on either half [pro] should-PL fall

'Then did they, at the alderman's prayer, make it so that the devils spoke, as was their wont, and said that a great battle was at hand, and on either side many men should fall.'

(ÆCHom II 280.23)

b. $\mathrm{Nu}$ sculon [pro] herigean heofonrices weard. now must [pro] praise heaven.kingdom-GEN warden 'Now we must praise the warden of the heavenly kingdom.'

(CædW-S 1)

c. ...pa var konongenom sact fra stæini pæim er then was king-DAT.DEF told from rock that COMP

hinn hælgi Olafr konongr fell a. the holy Óláfr king fell on

\footnotetext{
19 The text of the Old English examples is taken from the online Dictionary of Old English corpus at doe.utoronto.ca. The Old Norwegian example can be accessed at http://www.menota.org/DIPL_DG-8\%7C1-2.xml?side=41v. Both resources were retrieved on May 30, 2015.
} 
Oc enn kveða [pro] bloðe drivinn. and still say-3PL [pro] blood-DAT sprayed

'Then the king was told about the rock on which the holy king Óláfr fell. And people say that it is still sprayed with blood.'

(Óláfs saga ins helga, legendary version, 41v)

No overt antecedent matching the null subject is present in any of the examples above, none of which can be interpreted as topic drop.

As remarked above, certain aspects of the evidence from early Icelandic contrast with findings from other early Germanic languages. First, the longevity of the null subject property in Icelandic is remarkable in a cross-Germanic perspective. It has been documented that other Germanic languages, including English (Walkden 2013, 2014, Rusten 2013, 2015), German (Axel 2007), and Swedish (Håkansson 2008, 2013), lost the null subject property at much earlier stages. Additionally, it may be noted that null subjects are generally much more frequent in early Icelandic as compared to, for example, Old English and Old Swedish, where occurrence of null subjects is extremely restricted.

Second, as also mentioned above, null subjects have been shown to be considerably more frequent in main clauses than in subordinate ones in other early Germanic languages. This leads Walkden (2013) to suggest for Old English that null subjects may constitute a main clause phenomenon (in the sense of, for example, Hooper \& Thompson 1973, Green 1976, and Haegeman \& Ürögdi 2010). Data from some early Germanic languages could be taken as support for such a conclusion: In Old English (Walkden 2013, Rusten 2013, 2015), Old Saxon (Walkden 2014), and Old Swedish (Håkansson 2008, Håkansson 2013), null subjects are predominantly found in root environments, and only exceptionally in subordinate clauses. This clause asymmetry is also evident in the Old High German texts investigated by Axel (2007), although the overall frequencies for null subjects are much higher here than in the other languages. The Icelandic data, however, show that there is no distinction in null subject frequency between main and subordinate clauses, and even that null subjects are marginally more frequent in subordinate clauses than in main ones overall, across the period under investigation. This is unexpected in the context of early Germanic, suggesting that additional work still needs to be done on this topic. 


\section{Summary and Conclusion.}

This paper has presented the results of a large-scale, longitudinal corpusbased investigation of null subjects in Icelandic. Based on substantial data and regression analysis, we have provided robust empirical support for Hjartardóttir's (1987) claim that null subjects persist until a very late stage in Icelandic. We have also argued that there is evidence only for one licensing mechanism for null subjects in early Icelandic, contra Sigurðsson (1993). The findings also remain problematic for any analysis of null subjects that ties them to rich verbal agreement (as proposed, for instance, in Axel 2007 for Old High German and in van Gelderen 2013 for Old English), since there has been no real change in Icelandic verbal morphology over the last millennium. We have sketched a syntactic analysis which is based on Sigurðsson (2011), in combination with the assumption that pronouns may have different internal structure. On the basis of the position of the null subject and its person features, we have tentatively argued that the modern stage, where predominantly 3rd person pro-drop yields to a system permitting topic drop of all persons, arises in Icelandic in the early 20 th century.

\section{REFERENCES}

Axel, Katrin. 2007. Studies on Old High German syntax: Left sentence periphery, verb placement and verb-second. Amsterdam: John Benjamins. Axel, Katrin, \& Helmut Weiß. 2011. Pro-drop in the history of German from Old High German to the modern dialects. Null pronouns, ed. by Melani Wratil \& Peter Gallmann, 21-52. Berlin: De Gruyter.

Baayen, R. Harald. 2008. Analyzing linguistic data: A practical introduction to statistics using R. Cambridge: Cambridge University Press.

Barbosa, Maria do Pilar Pereira. 2009. Two kinds of subject pro. Studia Linguistica 63. 2-58.

Barbosa, Maria do Pilar Pereira. 2011. Partial pro-drop as Null NP Anaphora. LingBuzz: Electronic Archive of Linguistic Articles. Available at http://ling.auf.net/lingbuzz/001717.

Barbosa, Maria do Pilar Pereira. 2013. 'Pro' as a minimal NP: Towards a unified approach to 'pro'-drop. LingBuzz: Electronic Archive of Linguistic Articles. Available at http://ling.auf.net/lingbuzz/001949.

Barðdal, Jóhanna. 2001. Oblique subjects in Old Scandinavian. NOWELE 37. $25-51$. 
Barðdal, Jóhanna, \& Thórhallur Eythórsson. 2012. Reconstructing syntax: Construction grammar and the comparative method. Sign-based construction grammar, ed. by Hans C. Boas \& Ivan Sag, 257-308. Stanford, CA: CSLI Press.

Barton, Ellen L. 1998. The grammar of telegraphic structures. Sentential and nonsentential derivation. Journal of English Linguistics 26. 37-67.

Berndt, Rolf. 1956. Form und Funktion des Verbums in nördlichen Spätaltenglischen. Halle: Max Niemeyer.

Biberauer, Theresa. 2008. Introduction. The limits of syntactic variation, ed. by Theresa Biberauer, 1-72. Amsterdam: John Benjamins.

Biberauer, Theresa, Anders Holmberg, Ian Roberts, \& Michelle Sheehan. 2010. Parametric variation. Null subjects in Minimalist theory. Cambridge: Cambridge University Press.

Bopp, Franz. 1820. Analytical comparison of the Sanskrit, Greek, Latin, and Teutonic languages, showing the original identity of their grammatical structure. Annals of Oriental Literature 1. 1-65.

Bresnan, Joan, \& Höskuldur Thráinsson. 1990. A note on Icelandic coordination. Syntax and semantics. Modern Icelandic syntax, ed. by Joan Maling \& Annie Zaenen, 355-366. San Diego, CA: Academic Press.

Chomsky, Noam. 1982. Some concepts and consequences of the theory of Government and Binding. Cambridge, MA: MIT press.

Duarte, Maria Eugenia Lamoglia. 1995. A perda do princípio "evite pronome" no português brasileiro. Campinas, Brazil: Universidade Estadual de Campinas dissertation.

Déchaine, Rose-Marie, \& Martina Wiltschko. 2002. Decomposing pronouns. Linguistic Inquiry 33. 409-442.

Eggenberger, Jakob. 1961. Das Subjektspronomen im Althochdeutschen. Ein syntaktischer Beitrag zur Frühgeschichte des Deutschen Schrifttums. Zürich, Switzerland: University of Zürich dissertation.

Eythórsson, Thórhallur, \& Jóhanna Barðdal. 2005. Oblique subjects: A common Germanic inheritance. Language 81. 824-881.

Faarlund, Jan Terje. 1994. Old and Middle Scandinavian. The Germanic languages, ed. by Ekkehard König \& Johan van der Auwera, 38-71. London: Routledge.

Faarlund, Jan Terje. 2001. The notion of oblique subject and its status in the history of Icelandic. Grammatical relations in change, ed. by Jan Terje Faarlund, 99-135. Amsterdam: John Benjamins.

Faarlund, Jan Terje. 2004. The syntax of Old Norse. Oxford: Oxford University Press.

Faarlund, Jan Terje. 2013. The pro cycle. Argument structure in flux: The Naples-Capri papers, ed. by Elly van Gelderen, Jóhanna Barðdal, \& Michela Cennamo, 257-284. Amsterdam: John Benjamins. 
Faarlund, Jan Terje, Svein Lie, \& Kjell Ivar Vannebo. 1997. Norsk referansegrammatikk. Oslo: Universitetsforlaget.

Falk, Cecilia. 1992. Pro-drop in Early Modern Swedish. Folia Linguistica Historica 13. 115-123.

Falk, Cecilia. 1993. Non-referential subjects and agreement in the history of Swedish. Lingua 89. 143-180.

Falk, Hjalmar, \& Alf Torp. 1900. Dansk-Norskens syntax i historisk fremstilling. Kristiania: H. Aschehough.

Ferraresi, Gisella. 2005. Word order and phrase structure in Gothic. Leuven: Peeters.

Fertig, David. 2000. Null subjects in Gothic. American Journal of Germanic Linguistics and Literatures 12. 3-21.

Frascarelli, Mara. 2007. Subjects, topics and the interpretation of referential pro: An interface approach to the linking of (null) pronouns. Natural Language and Linguistic Theory 25. 691-734.

Gelderen, Elly van. 2000. A history of English reflexive pronouns. Person, self and interpretability. Amsterdam: John Benjamins.

Gelderen, Elly van. 2013. Null subjects in Old English. Linguistic Inquiry 44. 271-285.

Green, Georgia M. 1976. Main clause phenomena in subordinate clauses. Language 52. 382-397.

Haegeman, Liliane. 1990. Understood subjects in English diaries. Mulitilingua 9. 157-199.

Haegeman, Liliane, \& Barbara Ürögdi. 2010. Referential CPs and DPs: An operator-movement account. Theoretical Linguistics 36. 111-152.

Håkansson, David. 2008. Syntaktisk variation och forändring. En studie av subjektslösa satser i fornsvenska. Lund, Sweden: University of Lund dissertation.

Håkansson, David. 2013. Null referential subjects in the history of Swedish. Journal of Historical Linguistics 3. 155-191.

Haugan, Jens. 1998. Subjektet i passiv av norrøne dobbelt objektkonstruksjonar. Norsk Lingvistisk Tidsskrift 16. 157-184.

Hjartardóttir, Thóra Björk. 1987. Getið i eyðurnar. Reykjavik, Iceland: University of Iceland MA thesis.

Holmberg, Anders. 2005. Is there a little pro? Evidence from Finnish. Linguistic Inquiry 36. 533-564.

Holmberg, Anders. 2010. Null subject parameters. Biberauer, Holmberg, Roberts, \& Sheehan 2010, 88-124.

Holmberg, Anders, \& Christer Platzack. 1995. The role of inflection in Scandinavian syntax. New York, NY: Oxford University Press.

Holmberg, Anders, \& Ian Roberts. 2010. Introduction: Parameters in Minimalist theory. Biberauer, Holmberg, Roberts, \& Sheehan 2010, 1-57. 
Hooper, Joan, \& Sandra Thompson. 1973. On the applicability of root transformations. Linguistic Inquiry 4. 465-497.

Hróarsdóttir, Thorbjörg. 1996. The decline of OV word order in the Icelandic VP: A diachronic study. Working Papers in Scandinavian Syntax 57. 92-141.

Huang, Yan. 2000. Anaphora: A cross-linguistic study. Oxford: Oxford University Press.

Ingason, Anton Karl, Einar Freyr Sigurðsson, \& Joel C. Wallenberg. 2011. Distinguishing change and stability: A quantitative study of Icelandic oblique subjects, Philadelphia, PA: DiGS 13. Available at http:/www.linguist.is/ skjol/digs13oblique_slides.pdf/, accessed on May 30, 2015.

Jaeggli, Osvaldo, \& Kenneth J. Safir. 1989. The null subject parameter and parametric theory. The null subject parameter, ed. by Osvaldo Jaeggli \& Kenneth J. Safir, 1-44. Dordrecht: Kluwer.

Jenset, Gard B. 2010. A corpus-based study of the evolution of there. Statistical analysis and cognitive interpretation. Bergen, Norway: University of Bergen dissertation.

Johnson, Daniel Ezra. 2009. Getting off the GoldVarb standard: Introducing Rbrul for mixed effects variable rule analysis. Language and Linguistics Compass 3. 359-383.

Kinn, Kari. 2014. The cognitive status of null subject referents in Old Norse and their Modern Norwegian counterparts. Information structure and syntactic change in Germanic and Romance languages, ed. by Kristin Bech \& Kristine Gunn Eide, 173-200. Amsterdam: John Benjamins.

Kinn, Kari. 2015. Null subjects in the history of Norwegian. Oslo: Norway: University of Oslo Dissertation.

Korte, Siebe de. 2008. Dutch topic drop as a PF phenomenon. Amsterdam, the Netherlands: University of Amsterdam MA thesis.

Lander, Eric, \& Liliane Haegeman. 2014. Old Norse as an NP language: With observations on the Common Norse and Northwest Germanic runic inscriptions. Transactions of the Philological Society 112. 279-318.

Magnusson, Erik. 2003. Subject omission and verb initial declaratives in Swedish. Working Papers in Scandinavian Syntax 71. 103-143.

Modesto, Marcelo. 2000. Null subjects without "rich" agreement. The null subject parameter in Brazilian Portuguese, ed. by Mary Kato \& Esmerelda Negrão, 147-174. Frankfurt: Vervuert-Iberoamericana.

Mörnsjö, Maria. 2002. V1 declaratives in spoken Swedish. Syntax, information structure and prosodic pattern. Lund, Sweden: Lund University dissertation.

Mosteller, Frederick. 1968. Association and estimation in contingency tables. Journal of the American Statistical Association 321. 1-28.

Nygaard, Marius. 1894. Udeladelse av subjekt; 'subjektlöse' sætninger i det norröne sprog (den klassiske sagastil). Arkiv för Nordisk Filologi 10. 1-25.

Nygaard, Marius. 1906. Norrøn syntax. Kristiania: Aschehough. 
Nygård, Mari. 2013. Discourse ellipsis in spontaneously spoken Norwegian. Trondheim, Norway: Norwegian University of Science and Technology dissertation.

Ohlander, Urban. 1943. Omission of the object in English. Studia Neophilologica 16. 105-127.

Platzack, Christer. 1996. Null subjects, weak Agr and syntactic differences in Scandinavian. Studies in comparative Germanic syntax, vol. 2, ed. by Höskuldur Thráinsson, Samuel David Epstein, \& Steve Peter, 180-196. Dordrecht: Kluwer.

Pouplier, Marianne. 2003. Referential subject and object gaps in Icelandic. Nordlyd 31. 356-371.

Randall, Beth, Anthony Kroch, \& Ann Taylor. 2005-2013. CorpusSearch 2. Online. Available at http://corpussearch.sourceforge.net/, accessed on May 30, 2015.

Richards, Marc. 2015. Defective Agree, case alternations, and the prominence of person. Scales and hierarchies. A cross-disciplinary perspective, ed. by Ina Bornkessel-Schlesewsky, Andrej Malchukov, \& Marc Richards, 173-196. Berlin: De Gruyter.

Rizzi, Luigi. 1982. Issues in Italian syntax. Dordrecht: Foris.

Rizzi, Luigi. 1986. Null objects in Italian syntax and the theory of pro. Linguistic Inquiry 17. 501-557.

Rizzi, Luigi. 1997. The fine structure of the left periphery. Elements of grammar, ed. by Liliane Haegeman, 281-337. Dordrecht: Kluwer.

Roberts, Ian G. 1993. Verbs and diachronic syntax: A comparative history of English and French. Dordrecht: Kluwer.

Rögnvaldsson, Eiríkur. 1990. We need (some kind of) a rule of conjunction reduction. Syntax and semantics. Modern Icelandic Syntax, ed. by Joan Maling \& Annie Zaenen, 349-354. San Diego, CA: Academic Press.

Rögnvaldsson, Eiríkur. 1991. Quirky subjects in Old Icelandic. Papers from the Twelfth Scandinavian Conference of Linguistics, ed. by Halldór Á Sigurðsson, 369-378. Reykjavík: University of Iceland.

Rögnvaldsson, Eiríkur. 1995. Old Icelandic: A non-configurational language? NOWELE 26. 3-29.

Rosenkvist, Henrik. 2009. Referential null subjects in Germanic: An overview. Working Papers in Scandinavian Syntax 84. 151-180.

Ross, John R. 1982. Pronoun deleting processes in German. Paper presented at the Annual Meeting of the Linguistic Society of America held in San Diego, California, December 27-30, 1982.

Rusten, Kristian A. 2013. Empty referential subjects in Old English prose-a quantitative analysis. English Studies 94. 970-992. 
Rusten, Kristian A. 2015. A quantitative study of empty referential subjects in Old English prose and poetry. Transactions of the Philological Society 113. 53-75.

Sigurðsson, Halldór Á. 1989. Verbal syntax and case in Icelandic. Reykjavik, Iceland: University of Iceland dissertation.

Sigurðsson, Halldór Á. 1993. Argument-drop in Old Icelandic. Lingua 89. 247280.

Sigurðsson, Halldór Á. 2011. Conditions on argument drop. Linguistic Inquiry 42. 267-304.

Sigurðsson, Halldór Á., \& Verner Egerland. 2009. Impersonal null-subjects in Icelandic and elsewhere. Studia Linguistica 63. 158-185.

Stjernholm, Karine. 2008. Subjektsellipser: Fins pro i norsk talespråk? Oslo, Norway: University of Oslo MA thesis.

Tagliamonte, Sali A., \& R. Harald Baayen. 2013. Models, forests and trees of York English: Was/were variation as a case study for statistical practice.

Language Variation and Change 24. 135-178.

Taraldsen, Tarald. 1978. On the NIC, vacuous application and the that-trace filter. Bloomington, IN: Indiana University Linguistics Club.

Thráinsson, Höskuldur. 2007. The syntax of Icelandic. Cambridge: Cambridge University Press.

Thráinsson, Höskuldur, \& Thóra Björk Hjartardóttir. 1986. Pro-drop, topicdrop..: Where do Old and Modern Icelandic fit in? Scandinavian syntax, ed. by Östen Dahl \& Anders Holmberg, 150-161. Stockholm: University of Stockholm.

Trutkowski, Ewa. 2011. Referential null subjects in German. Proceedings of the Sixth Cambridge Postgraduate Conference in Linguistics (CamLing), ed. by Chris Cummins, Chi-Hé Elder, Thomas Godard, Morgan Macleod, Elaine Schmidt, \& George Walkden, 206-217. Cambridge: Cambridge Institute for Language Research.

Vance, Barbara. 1989. Null subjects and syntactic change in Medieval French. Ithaca, NY: Cornell University dissertation.

Walkden, George. 2013. Null subjects in Old English. Language Variation and Change 25. 155-178.

Walkden, George. 2014. Syntactic reconstruction and Proto-Germanic. Oxford: Oxford University Press.

Walkden, George. 2016. Null subjects in the Lindisfarne Gospels as evidence for syntactic variation in Old English. The Old English glosses to the Lindisfarne Gospels: Language, author and context (Buchreihe der Anglia), ed. by Julia Fernández Cuesta \& Sara M. Pons Sanz, 237-254. Berlin: De Gruyter. 
Wallenberg, Joel C., Anton Karl Ingason, Einar Freyr Sigurðsson, \& Eiríkur Rögnvaldsson. 2011. Icelandic Parsed Historical Corpus (IcePaHC).

Available at http://linguist.is/icelandic_treebank, accessed on May 30, 2015.

Weir, Andrew. 2012. Left-edge deletion in English and subject omission in diaries. English Language and Linguistics 16. 105-129.

Wendt, Bo-A. 2006. Vykortsstil i verkligheten. Elliptiskt och icke satsformat språkbruk i vykort. Lekt och lärt. Vänskrift till Jan Einarsson, ed. by Sofia Ask, Gunilla Byrman, Solveig Hammarbäck, Maria Lindgren, \& Per Stille, 244-295. Växjö: Växjö University Press.

Wiggen, Geir. 1975. Utelatelse av setningsledd. Norskrift 3. 1-47.

Zimmerman, Michael. 2014. Expletive and referential subject pronouns in Medieval French. Berlin: De Gruyter.

Kari Kinn

Department of Linguistics and Scandinavian Studies

P.O. Box 1102 Blindern

0317 Oslo

Norway

[kari.kinn@iln.uio.no]

Kristian A. Rusten

Department of English

Bergen University College

Inndalsveien

P.O. Box 7030

5020 Bergen

Norway

[kristian.andersen.rusten@hib.no]

George Walkden

School of Arts, Languages and Cultures

University of Manchester

Oxford Road

Manchester M13 9PL

United Kingdom

[george.walkden@manchester.ac.uk] 